\title{
POTENCIALIDADES DA INFRAESTRUTURA VERDE PARA UM HABITAR SISTÊMICO NO MEIO URBANO DE ALTA FLORESTA - MT
}

\author{
POTENCIAL OF GREEN INFRASTRUCTURE FOR SYSTEMIC URBAN \\ LIVING IN ALTA FLORESTA, MATO GROSSO - BRAZIL
}

POTENCIALIDADES DE LA INFRAESTRUCTURA VERDE PARA UN HABITAR SISTÉMICO EN LA CIUDAD DE ALTA FLORESTA, MATO GROSSO - BRASIL

1Programa de pós-graduação em Arquitetura e Urbanismo, Faculdade de Arquitetura e Urbanismo, Universidade de Brasília. Brasília, Distrito Federal, Brasil. pati.bioarquiteta@gmail.com ORCID: 0000-0002-2268-8622

2Programa de Pós-Graduação em Ciências Ambientais (PPGCA), Faculdade UnB Planaltina, Universidade de Brasília. Brasília, Distrito Federal, Brasil. rscorrea@unb.br ORCID: 0000-0002-9422-2629 


\title{
Resumo
}

O presente estudo tem como objetivo apropriar-se das potencialidades da infraestrutura verde (I.V.) como meio de planejar e gerir a cidade para um habitar sistêmico, considerando-a uma ferramenta essencial para a sustentabilidade territorial. Para tal, o trabalho aborda os papéis sociais e ecológicos das áreas verdes citadinas, com o intuito de promover qualidade de vida e garantir o equilíbrio dos sistemas naturais urbanos. Ressalta as inter-relações antrópicas e ambientais para a inclusão permanente do homem em seu habitat urbano e como metodologia, propõe a delimitação de estruturas ecológicas para a criação de uma rede de corredores verdes, a fim de qualificar a potencialidade de inserção de paisagens de alta performance no município de Alta Floresta (MT).

Palavras-Chave: infraestrutura verde; habitar sistêmico; corredores verdes; paisagens de alta performance; Alta Floresta (MT).

\begin{abstract}
This study aims to appropriate the potential of green infrastructure (GI) as a way to plan and manage cities for an urban systemic living as an essential tool for territorial sustainability. Approaches the social and ecological roles of green urban areas as an intrinsic part of the urban living, in order to promote quality of life and ensure the balance of urban natural systems. This work also highlights the anthropic and environmental interrelations aiming at the permanent inclusion of humans beings in their urban habitat. Has like a case study the city of Alta Floresta, Mato Grosso, Brazil, and proposes, through the delimitation of ecological structures, a network of green corridors to qualify the potencial for insertion of high performance landscapes in the municipality.
\end{abstract}

Key-Words: green infrastructure; systemic living; green corridors; high performance landscapes; Alta Floresta (Mato Grosso, Brazil).

\section{Resumen}

El presente estudio tiene como objetivo apropiarse de las potencialidades de la infraestructura verde (I. V.) como medio de planificación y gestión de la ciudad para un habitar sistémico, considerándolo una herramienta esencial para la sustentabilidad territorial. Para ello, aborda los roles sociales y ecológicos de las áreas verdes de la ciudad, con el fin de promover la calidad de vida y asegurar el equilibrio de los sistemas naturales urbanos. También destaca las interrelaciones antrópicas y ambientales para la inclusión permanente del hombre en su hábitat urbano. Su caso de estudio es la ciudad de Alta Floresta, Mato Grosso, Brazil, y propone, a través de la delimitación de estructuras ecológicas, una red de corredores verdes para calificar el potencial de inserción de paisajes de alto desempeño en el municipio.

Palabras clave: infraestructura verde; habitar sistémico; corredores verdes; paisajes de alta performance; Alta Floresta (Mato Grosso, Brazil). 


\section{Introdução}

Existe uma dependência entre todos os sistemas vivos que se interconectam por meio de processos físicos e vitais, propiciando a autossuficiência da biosfera e permitindo a existência na Terra (CAPRA, 2004). Essa relação dá forma à paisagem física e interfere intimamente na vida humana (RIBEIRO, 2010)

A busca pela sustentabilidade territorial está intrinsicamente ligada ao habitar humano. A adaptação do homem à vida moderna transformou o ecossistema e desenvolveu as cidades, ambientes predominantemente artificializados e desconectados com o ambiente natural. Reconhecer os sistemas ecológicos urbanos fundamentais e integrá-los à estrutura edificada é de suma importância para que de fato haja uma mudança de paradigma rumo ao desenvolvimento sustentável citadino.

Nessa perspectiva, tem-se o pensamento sistêmico, que abarca o ambiente urbano como um macrossistema complexo e multifacetado em subsistemas integrados e dinâmicos, em uma permanente inter-relação entre os agentes que o compõem (NACIFF, 2019).

Uma alternativa para compreender, planejar e gestar a cidade de forma sistêmica é por meio de sua infraestrutura verde definida como uma "rede de áreas naturais fundamentais para o funcionamento ecológico do território e para a preservação dos ecossistemas naturais, da vida selvagem, para a qualidade do ar e da água e para a qualidade de vida dos cidadãos" (FERREIRA, p. 69, 2010). A infraestrutura verde funciona como uma rede promotora de suporte da vida a partir da interação dos componentes ambientais, sociais e econômicos (BENNEDICT e MCMAHON, 2006). Trata-se, portanto, de ações conjuntas de gestão e crescimento territorial embasadas em valores de conservação ambiental para a proteção e integração dos elementos biofísicos, culturais, recreativos e paisagísticos de forma sustentável (FERREIRA e MACHADO, 2010; SANCHES, 2011), reconhecendo os sistemas ecológicos fundamentais integrados à implementação sustentável da estrutura edificada (FERREIRA e MACHADO, 2010) e do habitar humano.

Segundo Sanches (2011), a infraestrutura verde é parte do sistema metabólico da cidade e visa atuar em conjunto com outras infraestruturas, tais como: (a) mobilidade e acessibilidade ao estruturarem eixos de circulação e rotas para pedestres e ciclistas; (b) drenagem das águas pluviais, que regulam o ciclo hídrico; (c) lazer, recreação e convívio social e (d) manutenção ecológica do ecossistema, incrementando a conectividade dos fragmentos naturais por meio de corredores verdes. A criação de uma rede de corredores verdes promove a proteção dos recursos existentes e compatibiliza seu uso com as atividades humanas, contribuindo para melhoria da qualidade da paisagem e da vida da população (FERREIRA e MACHADO, 2010).

Uma rede de corredores verdes em ambiente urbano deve ser desenhada de forma a desempenhar funções ecológicas e sociais no território. As funções ecológicas englobam, entre outras, a manutenção da biodiversidade, filtro natural contra a poluição das águas e do ar, fixação de poeiras e proteção dos ventos, regularização de amplitudes térmicas e luminosidade atmosférica e circulação da água pluvial. Já as funções sociais remetem ao fornecimento de espaços para recreio ativo e lazer; melhoria do conforto ambiental; melhoria da qualidade do ar e preservação do patrimônio histórico e cultural (SANCHES, 2011). Sendo assim, entende-se, portanto, que a infraestrutura verde urbana engloba um conjunto de sistemas primordiais que dão suporte para a gestão e funcionamento urbano sustentável, onde os elementos que constituem a cidade interagem e se conectam entre si.

O presente artigo se desenvolve baseado nos princípios supracitados e por meio de um estudo, realizado com imagens aéreas do aplicativo Google Earth e acervo do núcleo de geotecnologias do 
ICV, mapas municipais disponibilizados pela prefeitura da cidade de Alta Floresta - MT e visitas in loco, propõe a criação de uma rede de corredores verdes para a cidade de Alta Floresta (MT) como base para um planejamento urbano sustentável. Através da sistematização e adaptação de diversos referenciais metodológicos, analisa, por meio de amostragem, um dos percursos criados a fim de avaliar a potencialidade de aplicação da infraestrutura verde para um habitar sistêmico no meio urbano local.

\section{O município de Alta Floresta - MT}

\subsection{A cidade planejada dentro da floresta.}

Como inúmeras cidades da região Centro Oeste e Norte do Brasil, Alta Floresta foi urbanizada por meio de um projeto de colonização privada em 1973, como parte da estratégia governamental de ocupação do território brasileiro pelo Programa de Integração Nacional. Impulsionados pelo discurso para a construção de um "novo país", a política de modernização do Brasil, iniciada pelo Presidente Juscelino Kubitschek de Oliveira, marca uma redistribuição geográfica da população brasileira com a abertura de novas fronteiras agrícolas e pecuárias em meio à implantação de novos núcleos urbanos, públicos e privados, quando diversas cidades foram projetadas sob a ideia de ordem, disciplina e organização, fundamentos inspirados no urbanismo racionalista de Le Corbusier, difundido e adotado em vários países (TOPANOTTI, 2016).

Nesse contexto, o município de Alta Floresta foi projetado para ser um grande polo da região norte mato-grossense. $O$ arquiteto e urbanista Luiz Antônio Vallandro Keating foi contratado pela empresa colonizadora INDECO S.A., organizando a cidade e seguindo as tendências modernistas de desenvolvimento da época. Idealizado para vinte mil pessoas, dentro de uma clareira na Floresta Amazônica, o município foi projetado a partir de uma malha viária hierarquizada (vide figura 1). Sua implantação iniciou-se a partir de um eixo monumental destinado às edificações públicas e institucionais, circundado por duas grandes avenidas que distribuem o fluxo dos carros para os setores residenciais ou unidades de vizinhança.. Cada setor residencial foi projetado para ser independente de outro, onde ruas coletoras interligam-se às vias de acesso local, as quais terminam em cul-de-sacs, fazendo limite com as grandes áreas verdes livres, projetadas para circulação de pedestres, ciclistas, lazer e conservação ambiental. Na periferia da cidade projetou-se um setor para as indústrias beneficiarem os produtos extraídos da região (TOPANOTTI, 2016). Dessa forma, a empresa colonizadora construiu a cidade em um quadrilátero de aproximadamente 1.060 hectares, que atraiu inúmeros migrantes rurais vindos principalmente da Região Sul do país em busca de terras férteis, e posteriormente ouro, proveniente dos garimpos que existiam na região. 
Figura 1: Perímetro urbano do Plano Piloto.

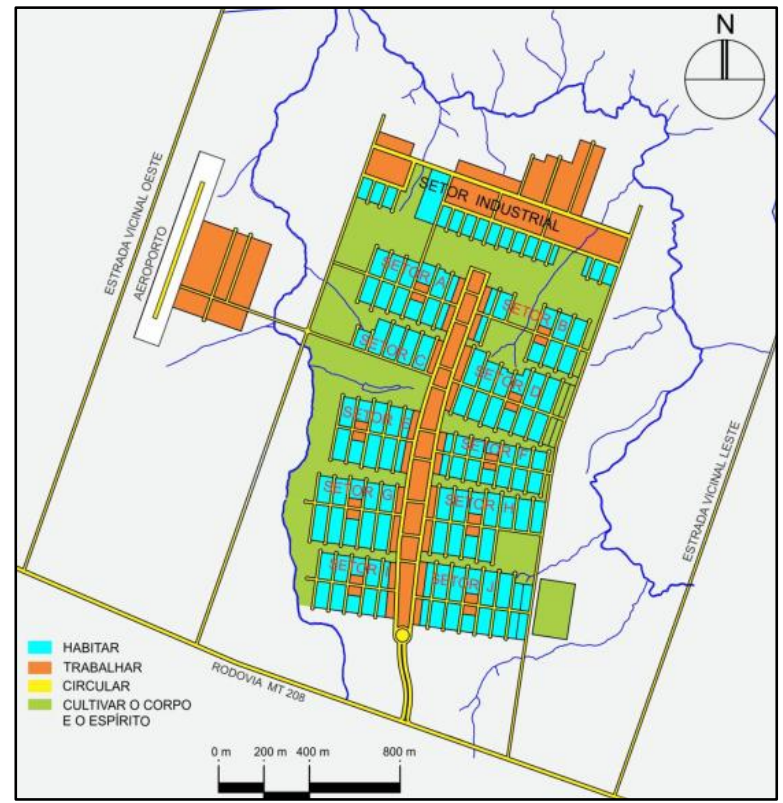

Fonte: TOPANOTTI, 2016

Figura 2: Área urbana do município.

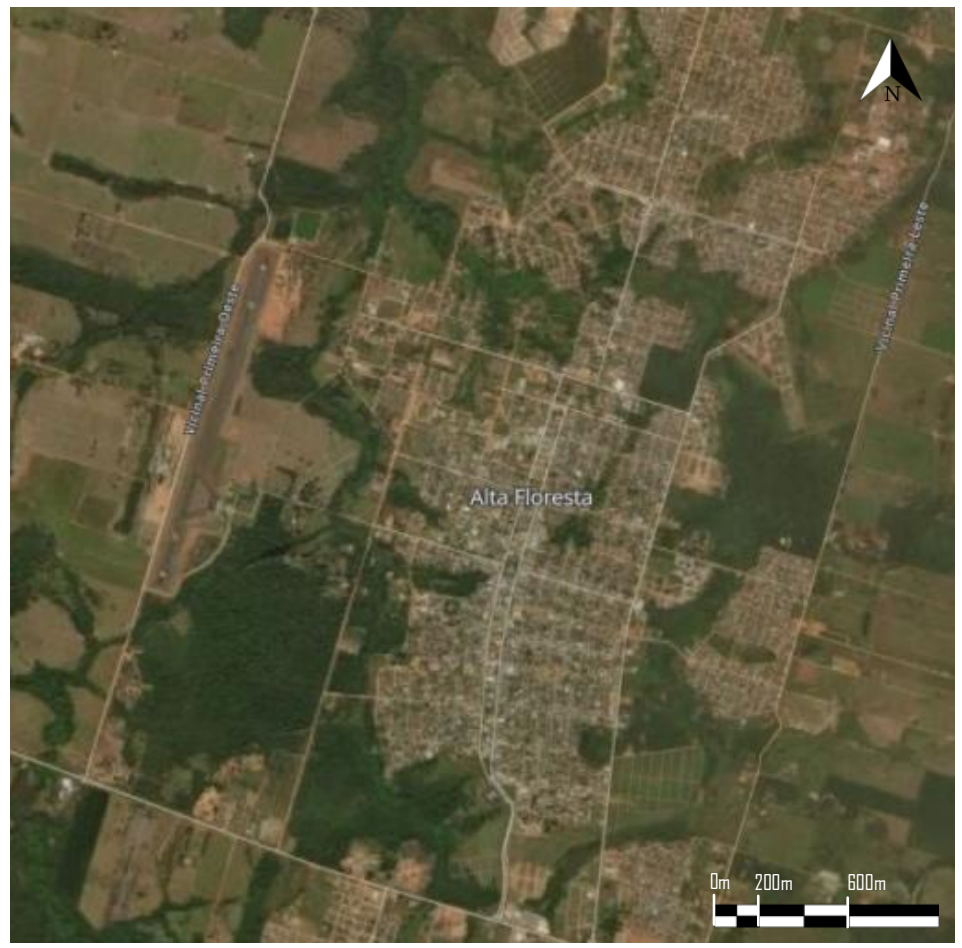

Fonte: Google Earth, 2020

O processo de implantação da cidade foi realizado em etapas: primeiramente foram construídos os três quilômetros do Eixo Monumental e setores residenciais iniciais, que posteriormente foram replicados ao longo das avenidas principais, totalizando dez setores. O superdimensionamento das vias projetadas também se estendeu às calçadas públicas e áreas verdes, que na prática, ganharam outros usos conforme se consolidaram. 
Os grandes recuos do Eixo Monumental, projetados para serem caminhos sombreados em meio aos remanescentes florestais, tornaram-se estacionamentos, e as áreas florestais lindeiras aos cul-de-sacs dos setores residenciais, destinadas à função de cultivar o corpo e o espírito, não foram consolidadas pela empresa colonizadora e nem pelo poder público quando a cidade foi emancipada no ano de 1979. Sendo assim, muitas das áreas que cumpririam a função de um corredor ecológico ao longo dos setores residenciais foram desflorestadas (TOPANOTTI, 2016). Sem uso adequado e tratamento paisagístico, no início dos anos 2000, parte desses lotes foi comercializado pelo poder público com o intuito de minimizar os custos de manutenção desses locais, diminuir a insegurança, reduzir o descarte de lixo inadequado e aumentar a arrecadação município, pontuando uma nova configuração urbana, juntamente com a formação de novos bairros periféricos e descontínuos do plano urbano inicial.

Atualmente, todos os setores residenciais criados no projeto inicial do município estão consolidados e os vazios dentro do perímetro urbano - exceto as áreas públicas - pertencem em sua maioria à família da empresa colonizadora, que vem implantando diversos loteamentos nessas áreas pertencentes à zona de expansão urbana criada no Plano Piloto da cidade. Porém, mesmo com a expansão imobiliária e a degradação de inúmeros fragmentos florestais urbanos, diversas áreas permanecem vegetadas, possibilitando a criação de corredores ecológicos baseados nos conceitos da infraestrutura verde, requalificando áreas potenciais previstas no plano urbano do município e conservando os remanescentes vegetativos existentes.

\subsection{As áreas verdes e sua contribuição para a Paisagem do município}

A extensão territorial urbana de Alta Floresta possui 3.792 hectares e as suas áreas de cobertura florestal contabilizam 739 hectares, correspondendo a $19,5 \%$ do total do espaço urbano (BATISTA et al, 2019). A vegetação é composta por Florestas Ombrófilas Estacionais Secundárias e os solos se caracterizam por Argissolo Amarelo, Latosssolo e solos Hidromórficos (BATISTA et al, 2019). Segundo Batista et al. 2019, diversos fragmentos florestais de vegetação secundária ainda podem ser encontrados no núcleo urbano do município, inclusive em grande parte nas Áreas de Preservação Permanente - APPs (Lei no 12.651/2012), potencializando a implantação de parques e corredores verdes (vide figura 3).

Por meio de estudo preliminar baseado em imagem aérea, é possível visualizar que diversos fragmentos vegetais no perímetro urbano de Alta Floresta se conectam ou estão próximos, o que favorece a implantação de projetos sistêmicos de infraestrutura verde com interligações entre áreas vegetadas remanescentes a praças, unidades de vizinhança, comércio e serviços, resignificando a Paisagem da cidade. 
Figura 3: Perímetro urbano e cobertura vegetal de Alta Floresta.

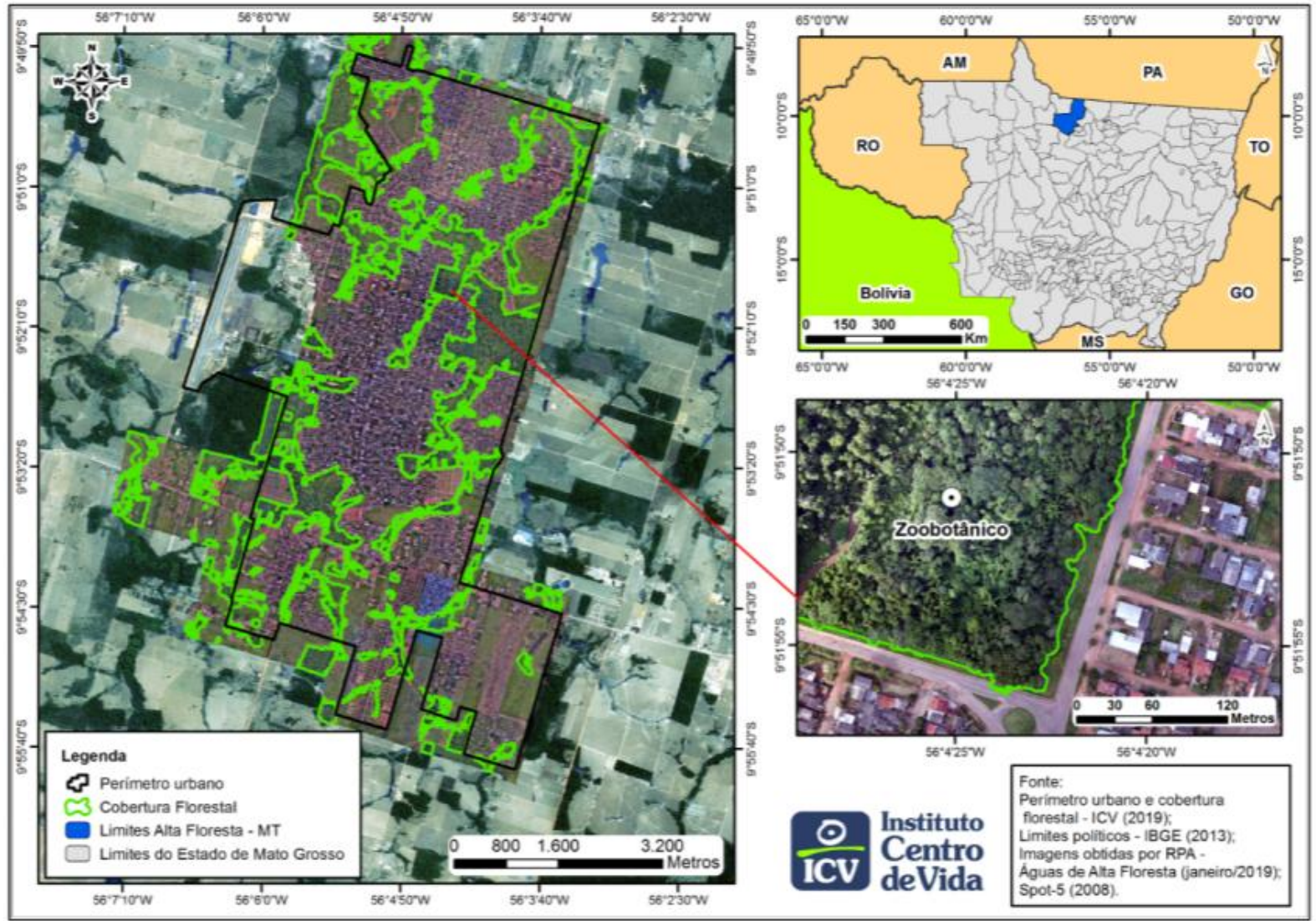

Fonte: Núcleo de Geotecnologias ICV, 2019.

Apesar das intervenções ocorridas ao longo dos anos após a colonização do município, os remanescentes vegetais se fazem presentes, interagindo com as áreas edificadas do Plano Piloto e expansão urbana. Além das áreas públicas destinadas a parques e praças, diversas glebas particulares compõem as áreas verdes da cidade, incluindo as linhas arbóreas ao longo das avenidas e ruas coletoras nos grandes recuos projetados por Keating na década de 1970.

Figura 4: Linhas arbóreas nas avenidas principais de Alta Floresta com predominância de Oitis (Licania tomentosa).

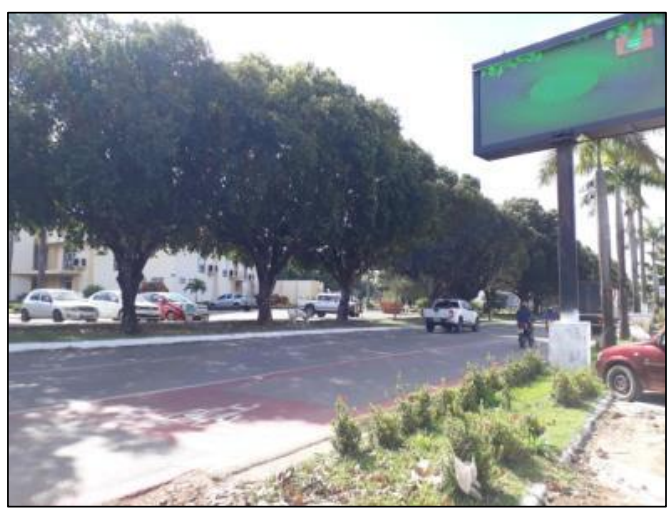

Figura 5: Vista aérea de fragmento florestal urbano em área edificada no município de Alta Floresta.

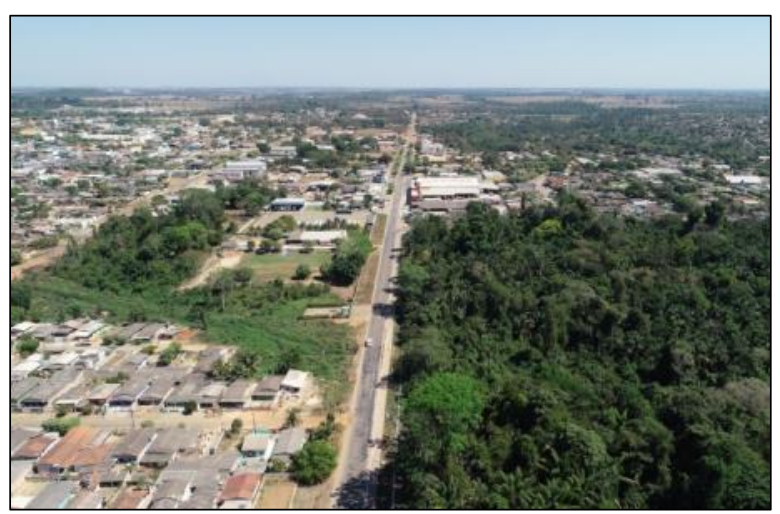




\section{Metodologia:}

A metodologia deste trabalho se desenvolveu em duas etapas: na primeira foram delimitadas quatro estruturas ecológicas para a criação de uma rede de corredores verdes no município em estudo (item 3.1), classificadas em dois grupos distintos, de acordo com Ferreira (2010): 1) Estrutura Ecológica Principal, com o objetivo de integrar as áreas que constituem o suporte dos sistemas ecológicos fundamentais para o funcionamento dos sistemas naturais presentes na área urbana, permanecendo o caráter non aedificandi e 2) Estrutura Ecológica Secundária, para "fomentar e intensificar os processos ecológicos em áreas edificadas" (FERREIRA, p. 78, 2010) e constituir eixos de paisagem de alta performance, com corredores de fauna, regulação climática, mobilidade, contemplação, recreação e conservação hídrica através da integração entre vias, espaços públicos, áreas edificadas e remanescentes vegetais.

Na segunda etapa, optou-se por avaliar uma das quatro estruturas ecológicas desenvolvidas (item 3.2). Para tal, foi realizada uma análise comparativa e adaptada de diferentes métodos para a qualificação de áreas vegetadas, baseada na pesquisa de Sanches 2011 e adaptadas a realidade local. A análise da estrutura ecológica em questão (Percurso 3) foi subdividida em quatro áreas de relevância, considerando três grupos fundamentais para o desenvolvimento urbano sustentável: grupo ecológico, grupo social e grupo hídrico, desenvolvidos no subitem 3.2.1 do presente artigo, com o intuito de comprovar a potencialidade da infraestrutura verde para uma habitar sistêmico no meio urbano do município.

\subsection{Identificação e mapeamento de áreas relevantes para a criação de uma rede de corredores verdes.}

A identificação e mapeamento das áreas relevantes se deram a partir da análise de imagens aéreas do aplicativo Google Earth, mapas do município disponibilizados pela Prefeitura de Alta Floresta e visitas in loco. Foram sistematizados por meio de três sistemas básicos da matriz constituinte da paisagem (FERREIRA 2010), conforme Figura 6:

- Sistema de linhas: constituído pelos elementos lineares da paisagem, como recursos hidrológicos, vegetação ripária, árvores plantadas em linha e eixos principais;

- Sistema de pontos: constituído por elementos pontuais da paisagem na escala de trabalho adotada, tais como praças e patrimônio construído;

- Sistema de áreas: constituído pelos remanescentes florestais na malha urbana.

Figura 6: Mapa esquemático do sistema básico da matriz constituinte da paisagem.

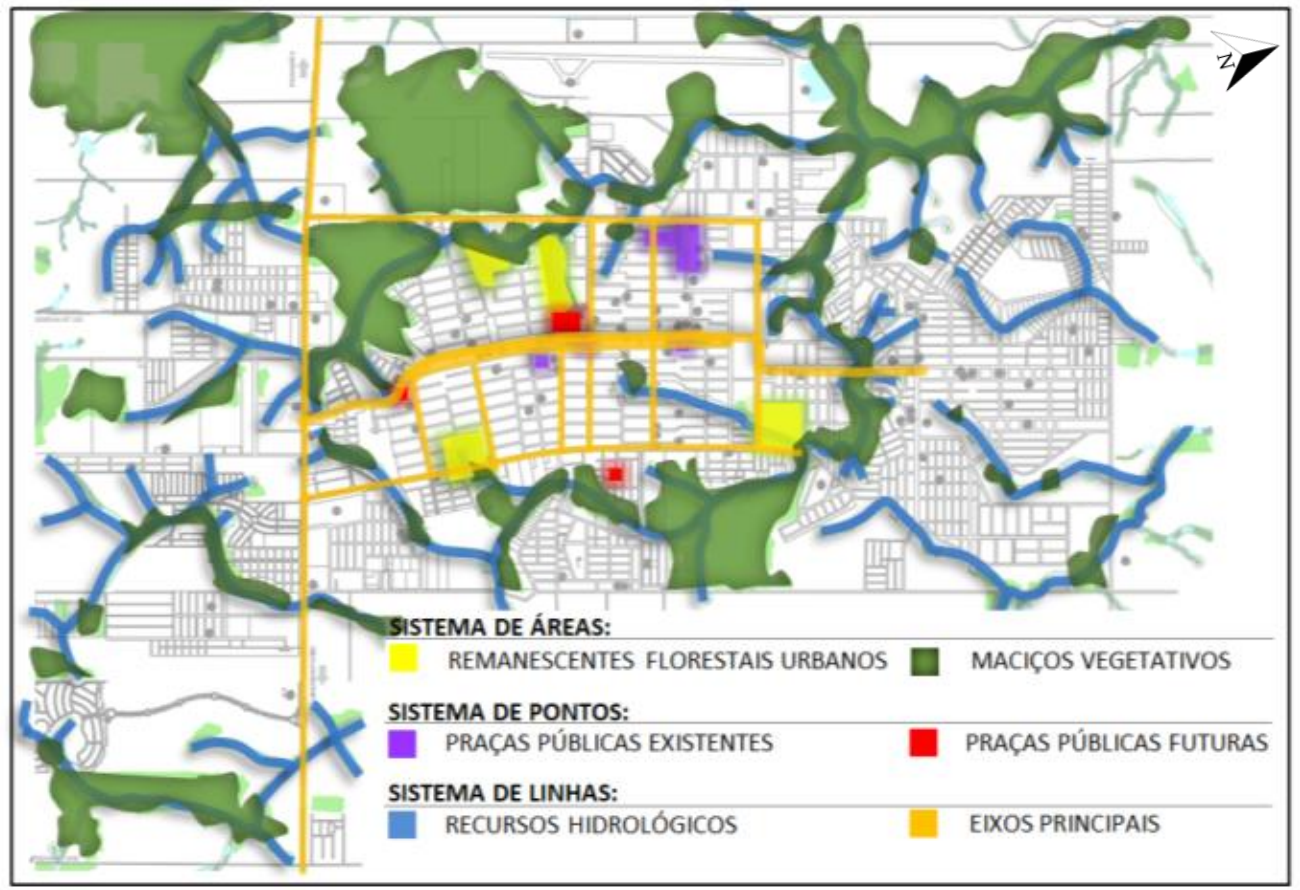


Com base no estudo de Ferreira (2010), foram traçadas quatro estruturas ecológicas potenciais para a criação da rede de corredores no município de Alta Floresta, representadas como percursos na figura abaixo:

Figura 7: Mapa das potenciais estruturas ecológicas representadas como percursos para implantação da rede de corredores verdes no município de Alta Floresta.

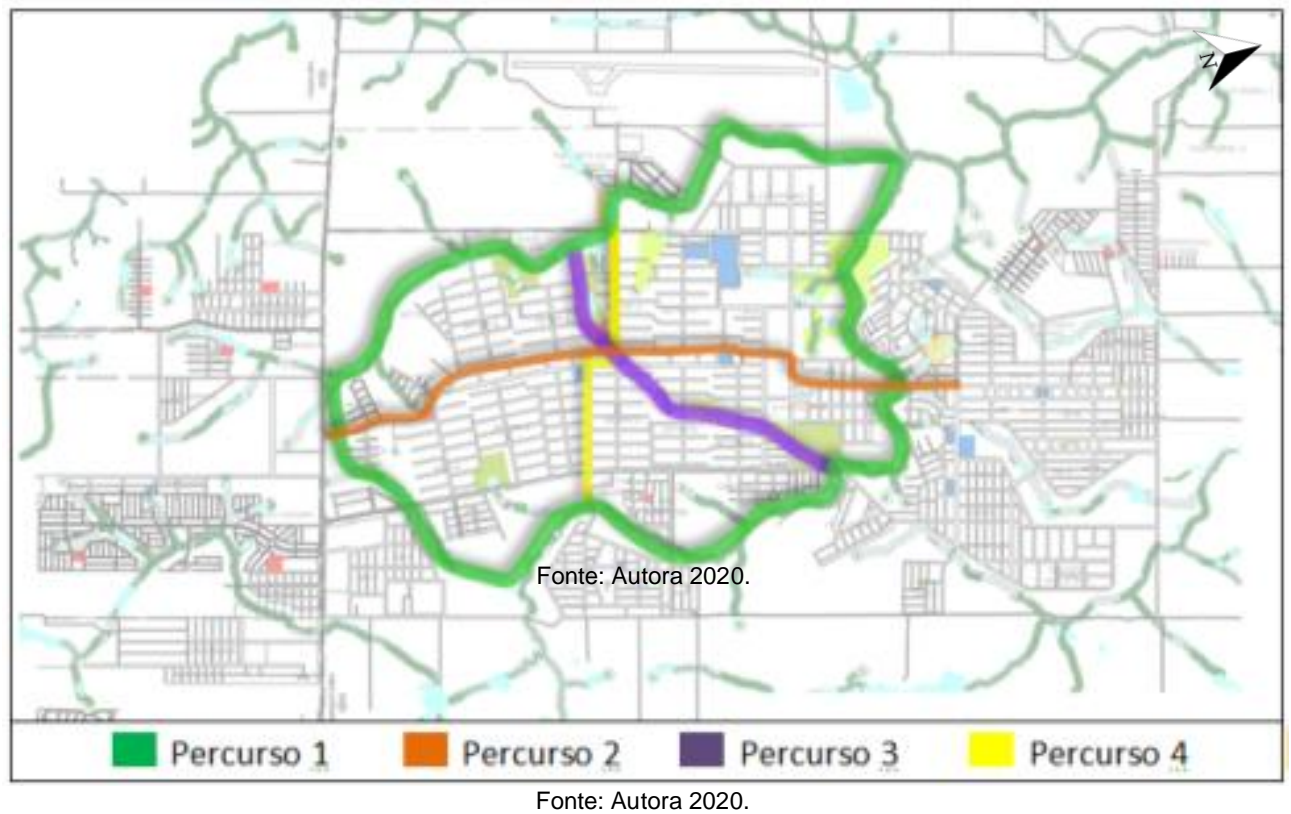

- Estrutura Ecológica 1: a paisagem ao longo do Percurso 1 caracteriza-se por remanescentes vegetativos em áreas públicas e particulares, sendo eles fragmentos florestais ou glebas. Abrange uma diversidade de recursos hidrológicos e compõe a Estrutura Ecológica Principal da rede traçada em uma concepção mais naturalista de conservação da biodiversidade.

Figura 8: Fragmento florestal (Percurso 1).

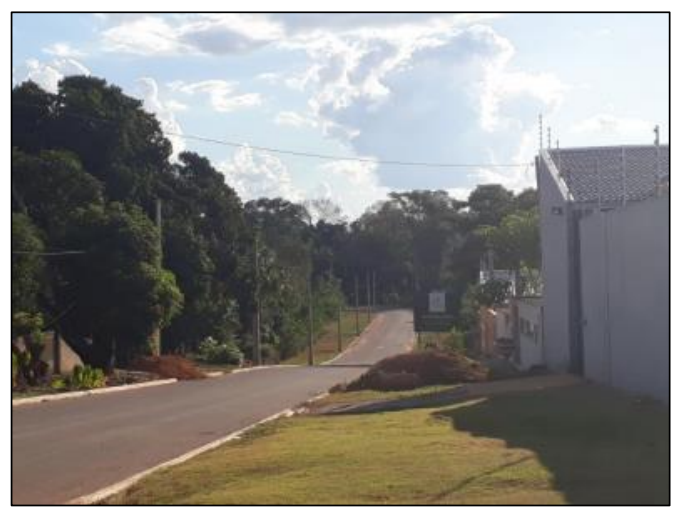

Fonte: Autora 2020
Figura 9: Fragmento florestal, Chácara Esteio (Percurso 1).

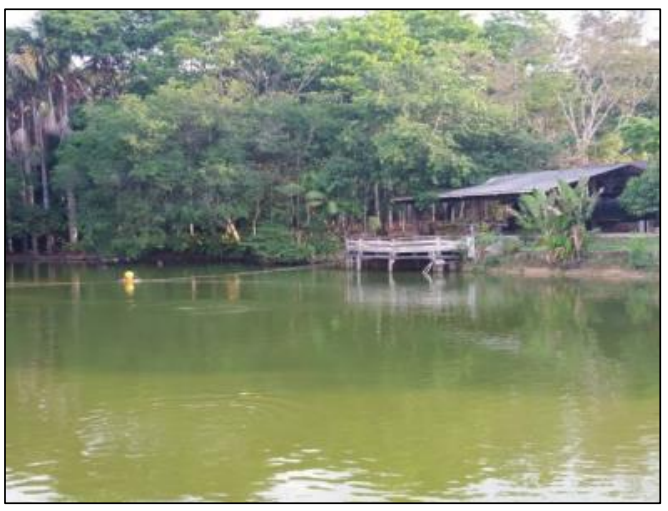

Fonte: Autora 2020

- Estrutura Ecológica 2: a paisagem ao longo do Percurso 2 enquadra-se na Estrutura Ecológica Secundária da rede traçada. Abrange o Eixo Monumental criado no Plano Piloto da cidade de Alta Floresta e caracteriza-se por duas avenidas de acesso e distribuição de fluxo aos bairros existentes no núcleo urbano. Linhas arbóreas, com predominância de Oitis (Licania tomentosa), delineiam os passeios dos recuos da área comercial de forma descontínua, diferente da ideia inicial do projeto de colonização do município, onde duas linhas arbóreas deveriam compor passeios sombreados, como já supracitado. Os grandes recuos frontais $(21 \mathrm{~m})$ são subutilizados como estacionamentos ao longo das duas vias, sendo elas de sentido único. Apesar da abundância espacial, a falta de um passeio 
adequado dificulta o percurso de pedestres. Também não existem faixas para circulação de meios de transportes alternativos, fazendo muitas bicicletas circularem na própria avenida e nos estacionamentos. Existe uma ciclofaixa demarcada sobre a via, porém ela só funciona no período noturno para fins recreativos. A estrutura ecológica criada se conecta a toda a rede de corredores delineada para este estudo, conforme figura 7 acima.

Figura 10: Avenida Ludovico da Riva, compondo o Eixo Monumental (Percurso 2).

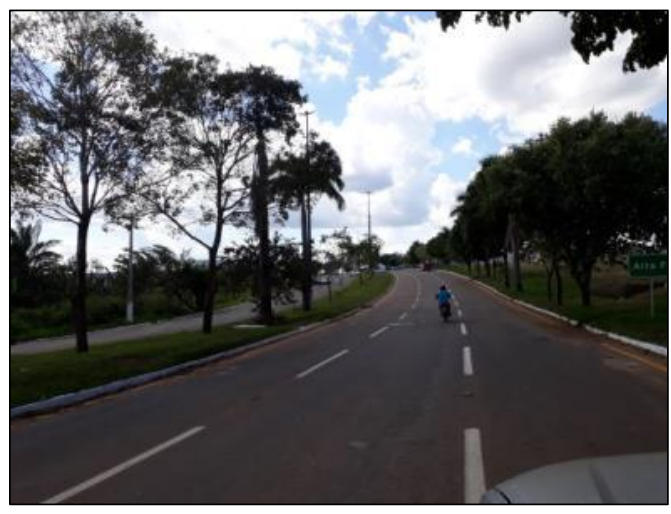

Fonte: Autora 2020
Figura 11: Avenida Ariosto da Riva, compondo o Eixo Monumental (Percurso 2).



Fonte: Autora 2020

A Estrutura Ecológica 3 (Percurso 3) compreende o foco do desenvolvimento deste trabalho e sua caracterização desenvolve-se no subitem 3.2 de forma mais abrangente.

- Estrutura Ecológica 4: a paisagem do Percurso 4 compõe a Estrutura Ecológica Secundária da rede proposta. Ela abrange duas vias coletoras relevantes no município, com intersecção com as avenidas principais e áreas vegetativas presentes no Percurso 1. Seu traçado foi delimitado de forma perpendicular ao Percurso 2 para que a rede criada se desenvolva de maneira equilibrada no tecido urbano (Figura 8). A maior praça pública da cidade compõe o percurso criado (Praça Cívica), além da existência de um parque natural em processo de requalificação (Parque das Capivaras). $O$ superdimensionamento do recuo frontal existente em umas das vias (24 m na Avenida C) está subutilizado e tem grande potencial para a implantação de equipamentos de lazer, mobilidade e conservação ambiental. Atualmente o acostamento dessa avenida é comumente utilizado por pedestres em caminhadas. A população se apropriou do espaço, consolidando sua vocação, apesar de sua falta de infraestrutura.

Figura 12: Praça Cívica como meio de intersecção entre os percursos desenvolvidos (Percurso 4).

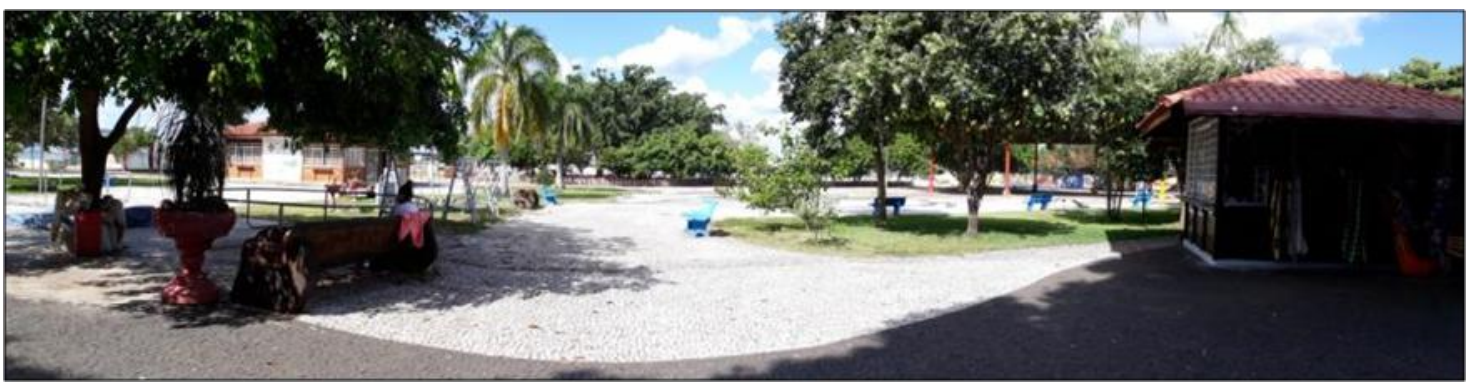

Fonte: Autora 2020. 
Figura 13: Avenida $C$ e os recuos potenciais para implantação de um corredor verde (Percurso 4).

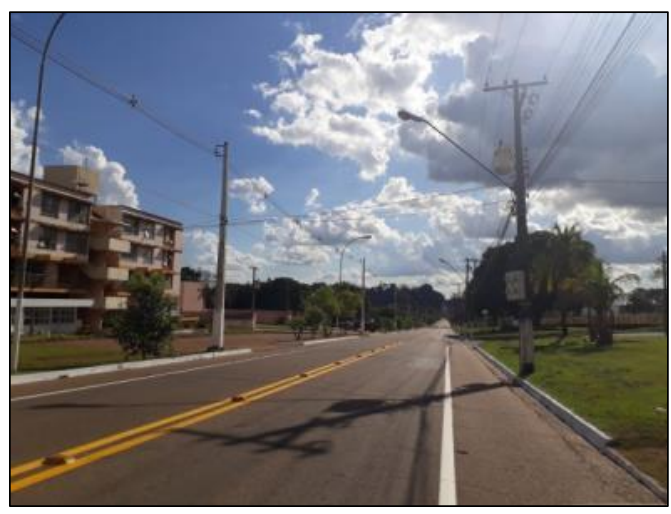

Fonte: Autora 2020
Figura 14: Avenida C e Parque das Capivaras em atual processo de requalificação (Percurso 4).

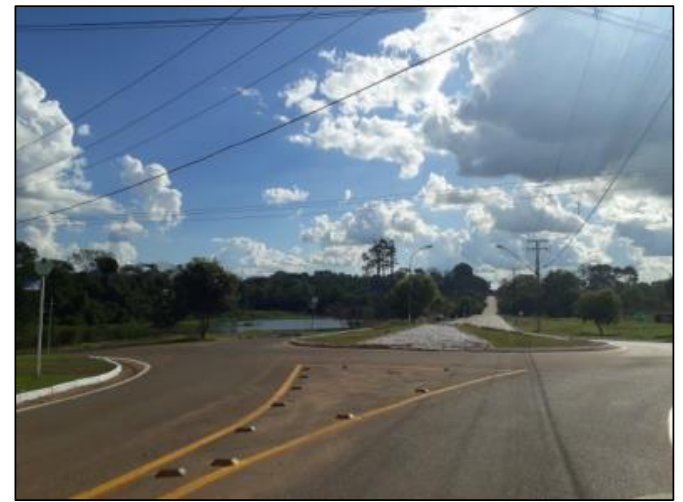

Fonte: Autora 2020.

\subsection{Potencialidades para a implantação de um corredor verde sistêmico.}

Nesta sessão pretende-se avaliar a potencialidade de aplicação da infraestrutura verde para a Estrutura Ecológica 3 (Percurso 3 ) da rede de corredores verdes estabelecida no subitem 3.1. Através da sistematização de diversos referenciais metodológicos desenvolvidos para a qualificação de espaços vegetados, realizou-se uma análise do percurso baseados em referenciais metodológicos sistematizados por Sanches (2011) e adaptados à realidade local.

A análise consolida-se por meio de três grupos funcionais (ecológico, hídrico e social) com critérios e indicadores avaliativos. Os valores obtidos foram valorados (de 0 a 1 ponto) e suas médias, relativas e absolutas, classificam em baixa, média ou alta potencialidade de inserção. Dessa forma, tem-se a seguinte classificação:

1. Grupo Ecológico: abarca conceitos de ecologia da paisagem, tratando-a como uma ciência interdisciplinar que lida com as interações antrópicas em seu habitat natural e construído (METZGER 2001). As áreas que compreendem este grupo classificam-se em três categorias:

a) matriz: áreas heterogêneas dominantes do local, conjunto de unidades de não habitat, em geral de origem antrópica, consideradas no presente estudo como a malha urbana (áreas residenciais, comerciais e mistas).

b) manchas: áreas homogêneas, minoritárias, restritas e não-lineares da paisagem que se distinguem das áreas vizinhas, consideradas aqui como parques, praças, várzeas, terrenos vazios, áreas degradadas e outros.

c) corredores: áreas homogêneas e lineares da paisagem que se distinguem das unidades vizinhas. Estruturam o sistema e conectam manchas verdes. São representados por matas ciliares, caminhos vegetados ao longo de recursos hídricos, linhas de alta tensão e outros.

Dessa forma, para a área em questão, tem-se a malha urbana de Alta Floresta como matriz, os parques C/E, Parque José Leopoldo Linhares Fernandes e Praça da Igreja Matriz como manchas e a vegetação ao longo da Área de Preservação Permanente do Córrego do Papai Noel e vias delimitadas como corredores, definindo assim o potencial ecológico do percurso desenhado, que foi baseado em três critérios e seus respectivos indicadores, que seguem abaixo:

a) Diversidade do habitat: objetiva avaliar por meio de indicadores as áreas com maior potencial de diversidade ecológica. Refere-se a (1) tamanho da área, compreendendo que áreas maiores apresentam maior potencial para abrigar maior diversidade de espécies e são menos vulneráveis a distúrbios externos (URGE, 2004, HERBST, 2001, FORMAN, 1995, RAMSTAD; OLSON; FORMAN, 1996 apud SANCHES 2011); (b) tamanho da área total, englobando, caso exista, a área natural preservada adjacente (SANCHES, 2011); (c) presença de massas adensadas de vegetação arbórea 
ou de várzea, diversificando e ampliando as variedades vegetais e animais presentes (SANCHES, 2011).

b) Conectividade das áreas verdes: objetiva compreender a conectividade das áreas delimitadas com outros remanescentes vegetativos, já que se entende que o incremento da biodiversidade está relacionado com a existência de corredores ecológicos ligados as manchas vegetais. Ressalta-se também a possibilidade de promoção e melhoria do valor recreacional dessas áreas (HERBST, 2001; THRALL, 1988; STAPLES, 2006 apud SANCHES 2011). O indicador utilizado para tal é a distância entre a área avaliada até o fragmento mais próximo.

c) Prioridade de restauração ecológica: objetiva priorizar a restauração de áreas protegidas por lei e importância ecológica, consideradas prioritárias para recomposição vegetal (THRALL, 2006 apud SANCHES, 2011). O indicador define-se pela presença Áreas de Preservação Permanente.

2. Grupo Hídrico: considera o potencial das áreas em conduzir as águas com segurança, reduzindo os riscos de inundações, melhoria da qualidade das águas e contribuição para a regulação do ciclo hídrico (SANCHES, 2011), através de dois indicadores:

a) Potencial de retenção das águas: objetiva avaliar se a área encontra-se em zona de risco de inundação já que os locais passíveis de alagamento convertidos em áreas verdes retardam a vazão das águas pluviais, diminuem o escoamento superficial e contribuem para a recarga das águas subterrâneas (SANCHES, 2011).

b) Potencial de purificação das águas: objetiva avaliar o potencial de purificação das águas através da vegetação existente por meio de dois indicadores: (1) presença de curso d'água e se esse se encontra ou não canalizado, agregando valores ecológicos com o aumento da biodiversidade e sociais na interação do mesmo com a população (HERBST, 2001; SANCHES, 2011) e (2) identifica a presença de vegetação ripária ou alagados naturais nos cursos d'água existentes, já que a vegetação pode agir como elemento filtrante de partículas e de poluição difusa, além de impedir o assoreamento dos rios e córregos, restabelecendo o ecossistema local (SANCHES, 2011).

3. Grupo Social: pondera a interação das áreas verdes com as relações sociais, tais como recreação, lazer, práticas esportivas, contemplação, mobilidade e circulação de pessoas. Desenvolve-se por meio de três critérios:

a) Mobilidade: considera a existências de áreas com dimensões de quadra ou lineares de grande extensão para a formação de rotas alternativas para pedestres e ciclistas, estabelecendo diversas relações de circulação e fluxo com o entorno (SANCHES, 2011).

b) Acessibilidade: considera a praticidade de a população percorrer e frequentar as áreas verdes. Tem como indicadores: (1) acessibilidade à área por transporte público e (2) presença de ruas dentro do remanescente vegetal, fragmentando a área e prejudicando o fluxo de algumas atividades e do tráfego das pessoas. Nesse caso, como solução propõe-se sinalização redobrada para condutores de veículos, diferenciação de pisos, faixas e passarelas de conexão (SANCHES, 2011).

c) Potencial de uso pela comunidade: Identifica fatores que maximizem o uso das áreas verdes pelos munícipes. Tem como indicadores: (1) densidade geográfica (dentro do raio de $500 \mathrm{~m}$ ), onde as áreas que compreendem maior densidade populacional tem prioridade em serem requalificadas (HERBST, 2001), (2) uso do solo do entorno, sendo que os usos residenciais e mistos possuem maior valor que 0 industrial (STAPLES, 2006 apud SANCHES, 2011) e (3) proximidade a equipamentos culturais (museu, biblioteca, teatro) e escolas, pois essas áreas podem ser utilizadas como extensão das atividades propostas desses equipamentos, permitindo ainda um contato diário com a natureza em um raio de 500 m (HERBST, 2001; STAPLES, 2006 apud SANCHES, 2011)

\subsubsection{Caracterização do estudo de caso: Estrutura Ecológica 3.}

O Percurso 3 compõe a Estrutura Ecológica Secundária da rede proposta. Ele possui 2,9 $\mathrm{km}$ de extensão e conecta dois relevantes maciços vegetativos urbanos, o Parque C/E e o Parque José Leopoldo Linhares Fernandes, a Área de Preservação Permanente do Córrego do Papai Noel e a Praça da Igreja Matriz do município (vide Figura 15). 
Figura 15: Percurso eleito para estudo de caso (áreas de relevância: A: Parque C/E, B: Praça da Igreja Matriz e corredor de ligação, C: Área de Preservação Permanente do Córrego Papai Noel e D: Parque José Leopoldo Linhares Ferreira).

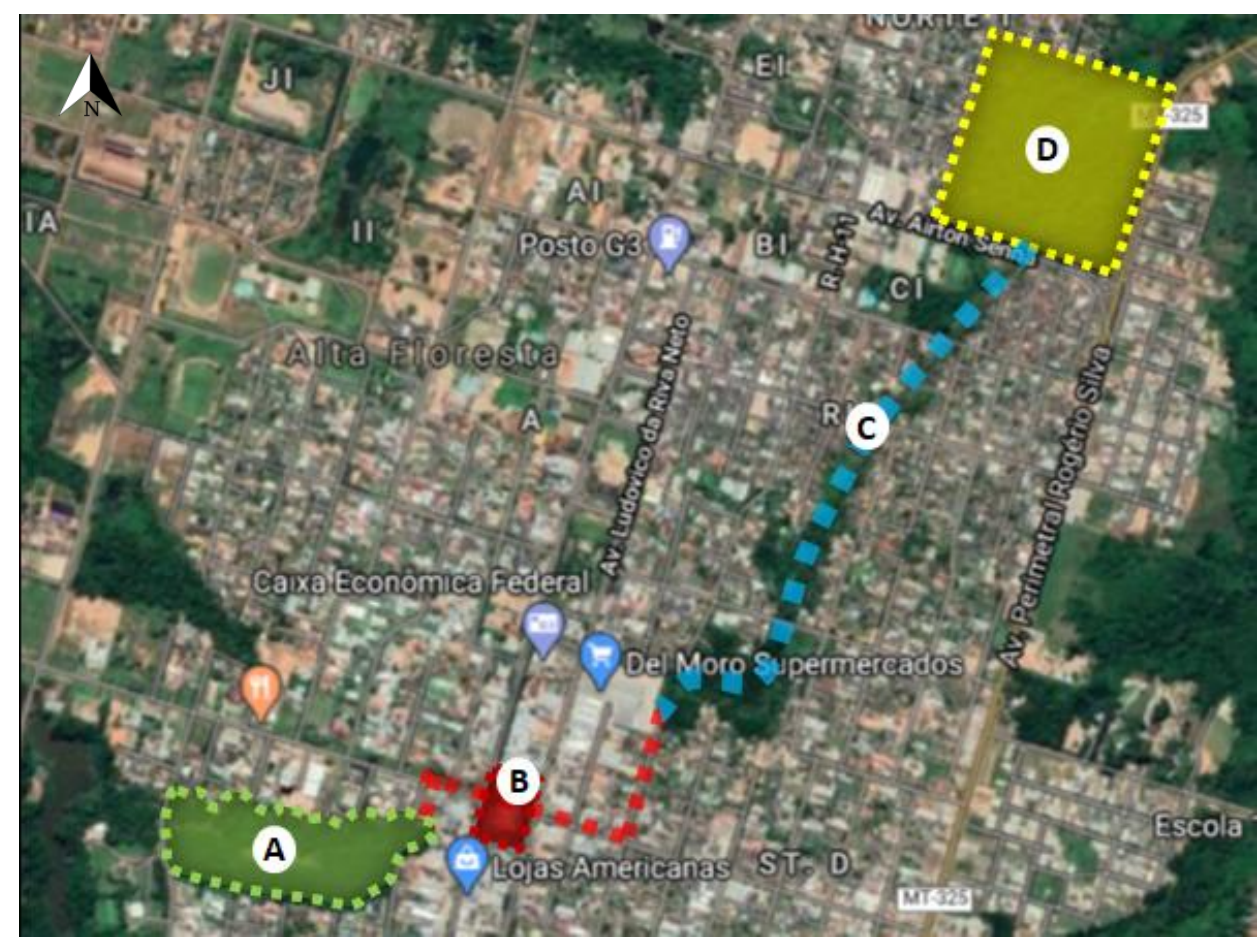

Fonte: Autora 2020.

\section{- Área de relevância A: Parque C/E.}

O Parque C/E compreende uma área de 9.315 ha, caracteriza-se como um maciço de Floresta Ombrófila Densa em estágio secundário na área urbana e possui duas nascentes hídricas com áreas alagadiças. Ele compreende uma das áreas verdes criadas no Plano Piloto do município para os setores residenciais da matriz urbana, no qual as vias do entorno são cul de sacs e localiza-se na parte central da cidade, nas proximidades do Eixo Monumental. Apesar da grande potencialidade da área para ser utilizada como um parque, o remanescente não possui infraestrutura para que possa ser utilizado pela população. A mancha florestal no Parque é interligada a dois fragmentos florestais adjacentes de propriedade particular, um com aproximadamente 235 ha e outro com 140 há. Eles abrangem o Percurso $1 \mathrm{e}$ foram indicados neste trabalho (vide figura 7) como apresentando potencial para integrarem a rede de corredores verdes no município. A ligação do Parque C/E no percurso em análise se estabelece por uma das vias locais em direção a uma via coletora (Avenida C) desenvolvida no Percurso 4, que possui recuos frontais de $24 \mathrm{~m}$ subutilizados e com grande potencial para a reabilitação e criação de equipamentos de lazer, recreação, contemplação e mobilidade sustentável. 
Figura 16: Parque C/E tracejado em verde e fragmento florestal adjacente.

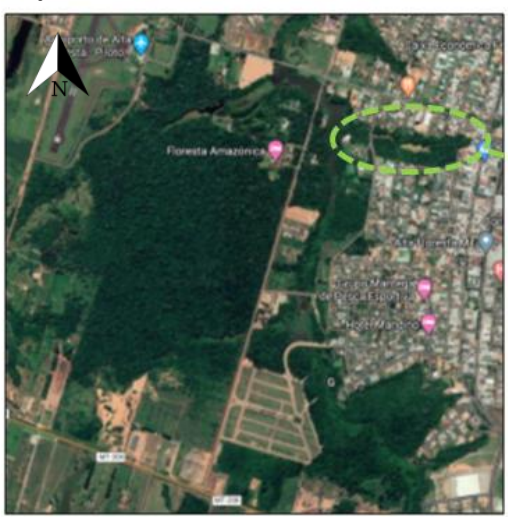

Fonte: Google Earth 2020, adaptado pela autora.

Figura 18: Parque C/E no setor habitacional do Plano Piloto em rua com cul de sac (referenciado na Figura 18, assinalado como $\mathrm{n}^{0}$ 2).

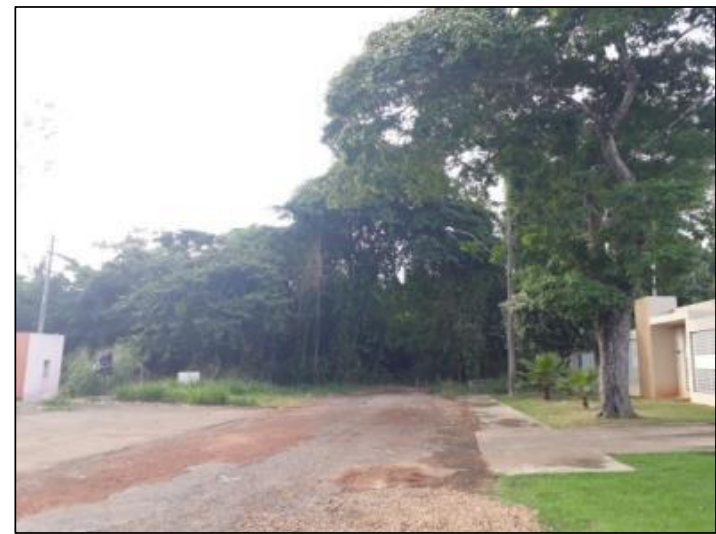

Fonte: Autora 2020
Figura 17: Parque $\mathrm{C} / \mathrm{E}$ tracejado em verde e corredor de ligação com a Praça da Igreja Matriz em vermelho.

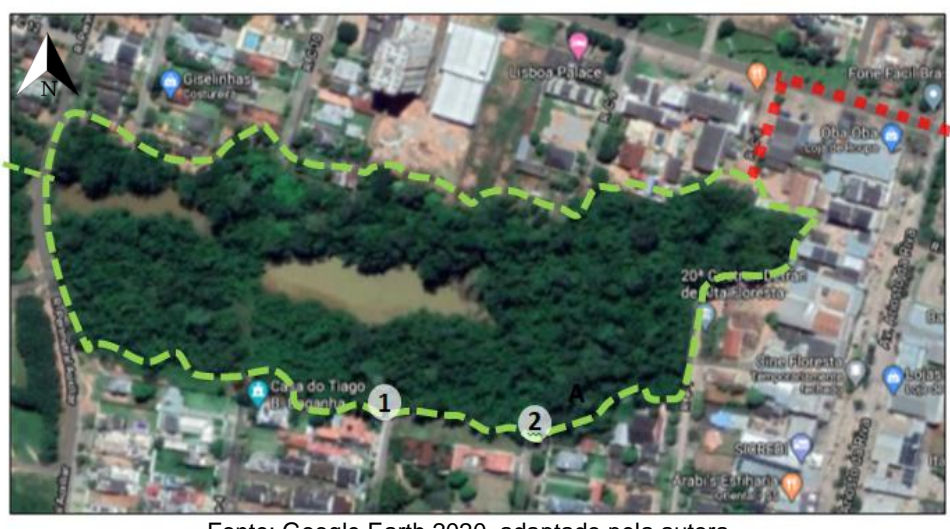

Fonte: Google Earth 2020, adaptado pela autora.

Figura 19: Divisa do Parque C/E no setor habitacional do Plano Piloto (referenciado na Figura 17, assinalado como no 1 ).

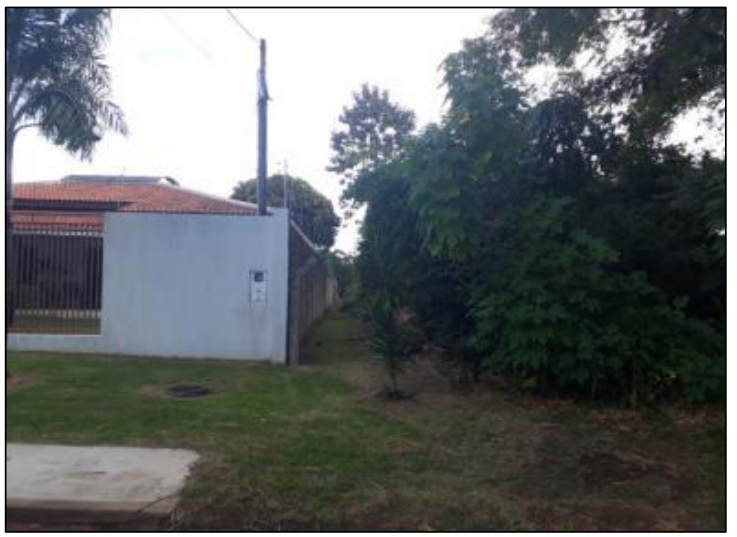

Fonte: Autora 2020.

\section{- Área de relevância B: Praça da Igreja Matriz.}

A Praça da Igreja Matriz localiza-se dentro no Eixo Monumental projetado no Plano Piloto do município Possui 1,57 hectares, sendo 0,65 ha de área impermeabilizada por edificação, passeios e estacionamento. A área verde presente caracteriza-se pela predominância de Oitis (Licania tomentosa) na arborização urbana, além de pequenos jardins gramados com algumas plantas exóticas de portes médio e baixo ao longo dos passeios projetados. Seu uso é basicamente de passagem no centro comercial do qual faz parte. No percurso desenvolvido neste estudo, ela compõe o eixo de ligação entre os fragmentos vegetados existentes (Parque C/E e APP Córrego do Papai Noel) por meio de duas avenidas coletoras (Avenida C e Ulisses Guimarães), que atuam como corredores verdes, conforme a Figura 20. 
Figura 20: Praça da Igreja Matriz (sombreada em vermelho) e eixo de ligação entre os remanescentes vegetais urbanos no percurso desenvolvido, sendo A o Parque C/E e C a Área de Preservação Permanente do Córrego do Papai Noel. A demarcação em amarelo exalta os recuos subutilizados da Avenida C, com potencial para a implantação de um corredor verde, com melhor detalhamento na figura 23.

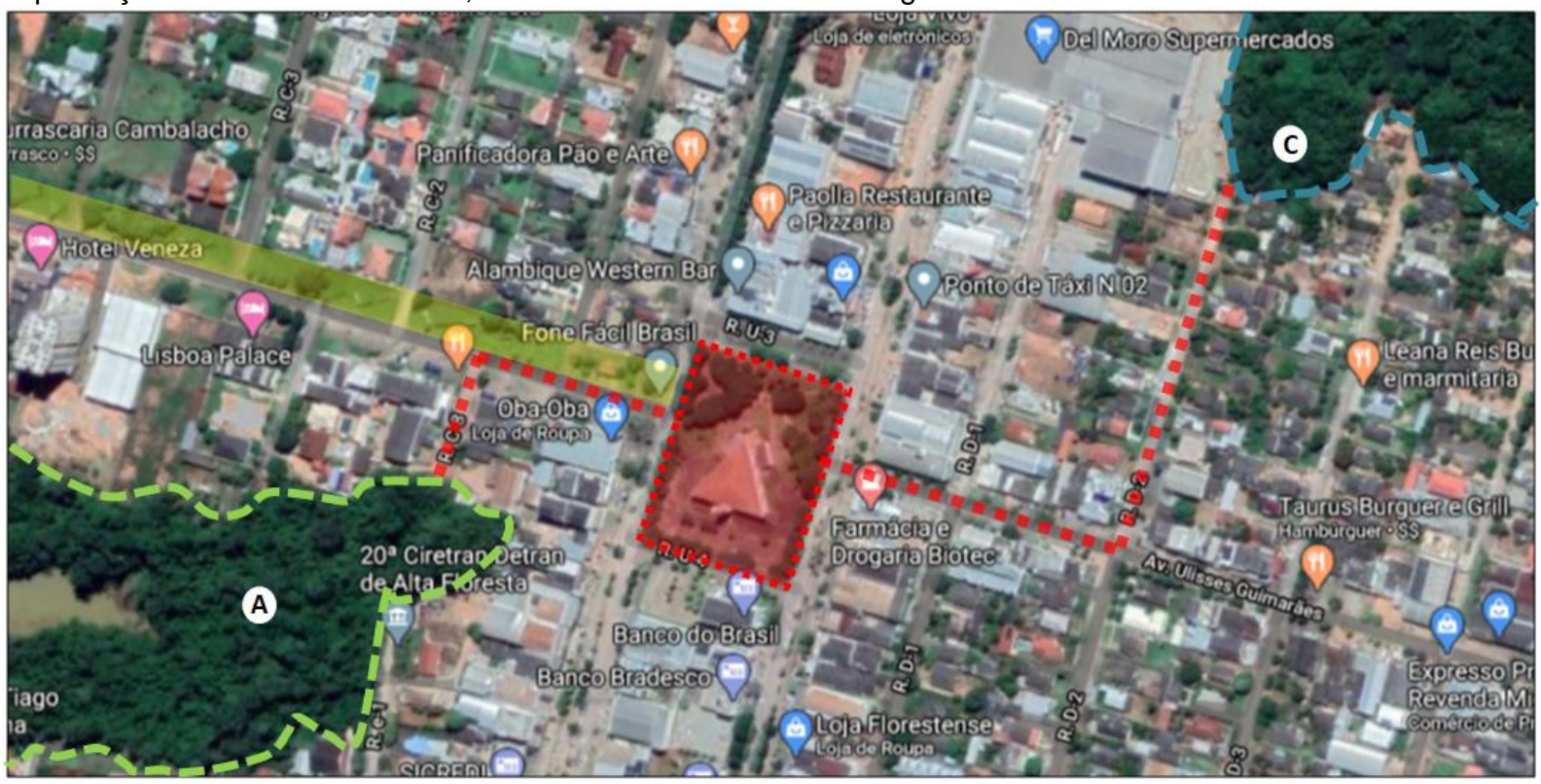

Fonte: Autora 2020

Figura 21: Vista aérea da Praça da Igreja Matriz no Eixo Monumental.

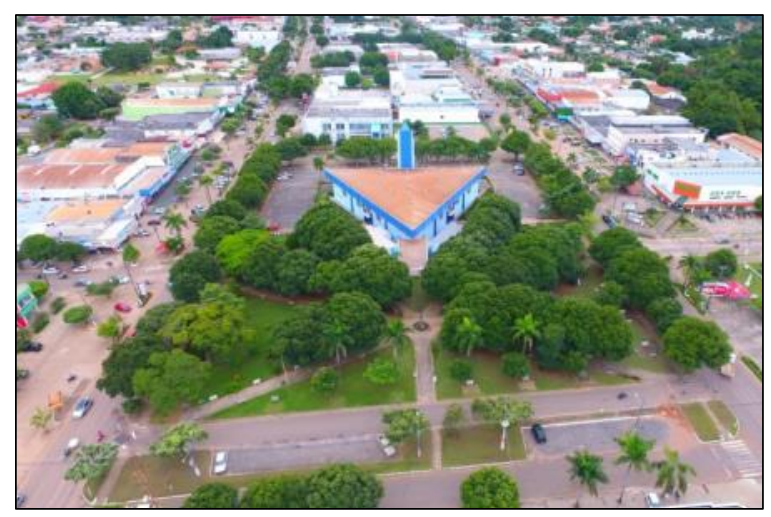

Fonte: Nativanews 2020.
Figura 22: Praça da Igreja Matriz.

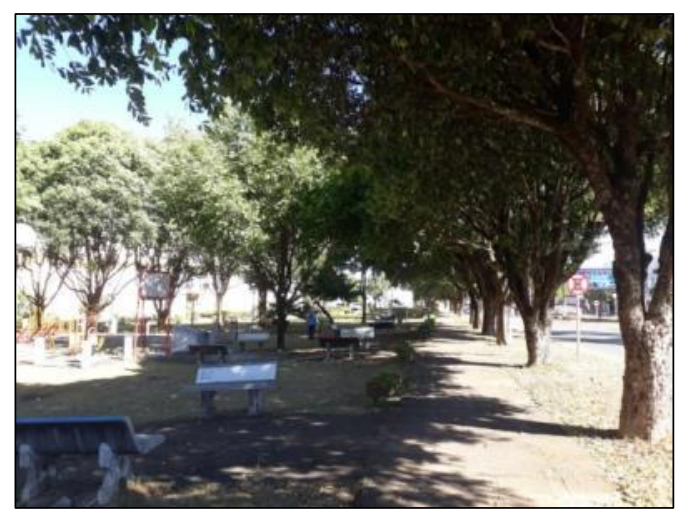

Fonte: Autora 2020. 
Figura 23: Avenida $C$ e recuos subutilizados.

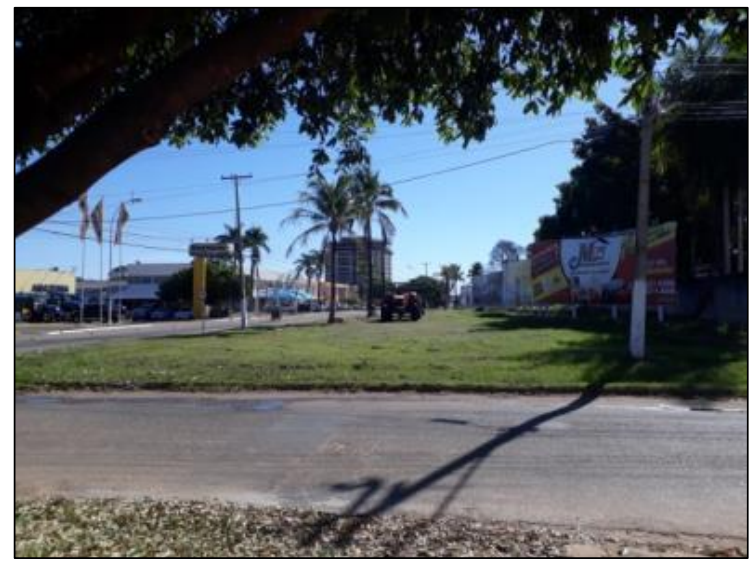

Fonte: Autora 2020
Figura 24: Rua D-2, com ênfase nos grandes recuos e rua em cul de sac para acesso à Área de Preservação Permanente do Córrego do Papai Noel (ao fundo) como limite entre as áreas verdes e setor habitacional criado no Plano Piloto.

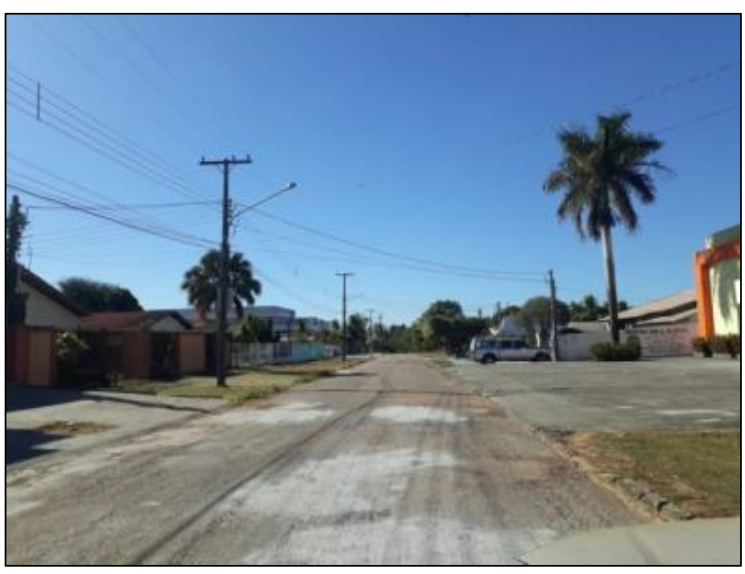

Fonte: Autora 2020

\section{- Área de relevância C: Área de Preservação Permanente do Córrego Papai Noel.}

O Córrego do Papai Noel representa um recurso hídrico presente no núcleo urbano projetado no Plano Piloto do município de Alta Floresta. Ele abrange algumas das áreas sob cobertura vegetal destinadas à circulação de pedestres entre os cul-de-sacs propostos. O Córrego do Papai Noel perdeu grande parte de suas características originais em razão da expansão das atividades antrópicas, possui ocupações irregulares em Áreas de Preservação Permanente (vide figura 28), tais como habitações precárias e edificações comerciais (vide figura 29). Parte das construções existentes se consolidam nos terrenos vendidos pelo poder público, conforme supracitado do item 2.1 deste artigo, onde algumas áreas verdes foram loteadas.

Apesar da degradação existente, ainda existem fragmentos remanescentes de Matas Ciliares ao longo do Córrego. Nas épocas de chuvas, há alagamentos na área mais adensada e carente, obrigando os moradores a tomarem providencias improvisadas (vide Figura 27) para protegerem suas residências. Dessa forma, entende-se a necessidade em restaurar a vegetação da Área de Preservação Permanente do Córrego do Papai Noel e implementar medidas baseadas na infraestrutura verde, a fim de recuperar paisagem vegetal e proporcionar qualidade de vida à população. Por se tratar de uma área situada em local nobre do perímetro urbano, também ressalta-se a oportunidade de ela ser utilizada como eixo de mobilidade sustentável. 
Figura 25: Vista parcial da microbacia do Córrego do Papai Noel, com indicação de ponto referencial na Figura 27.

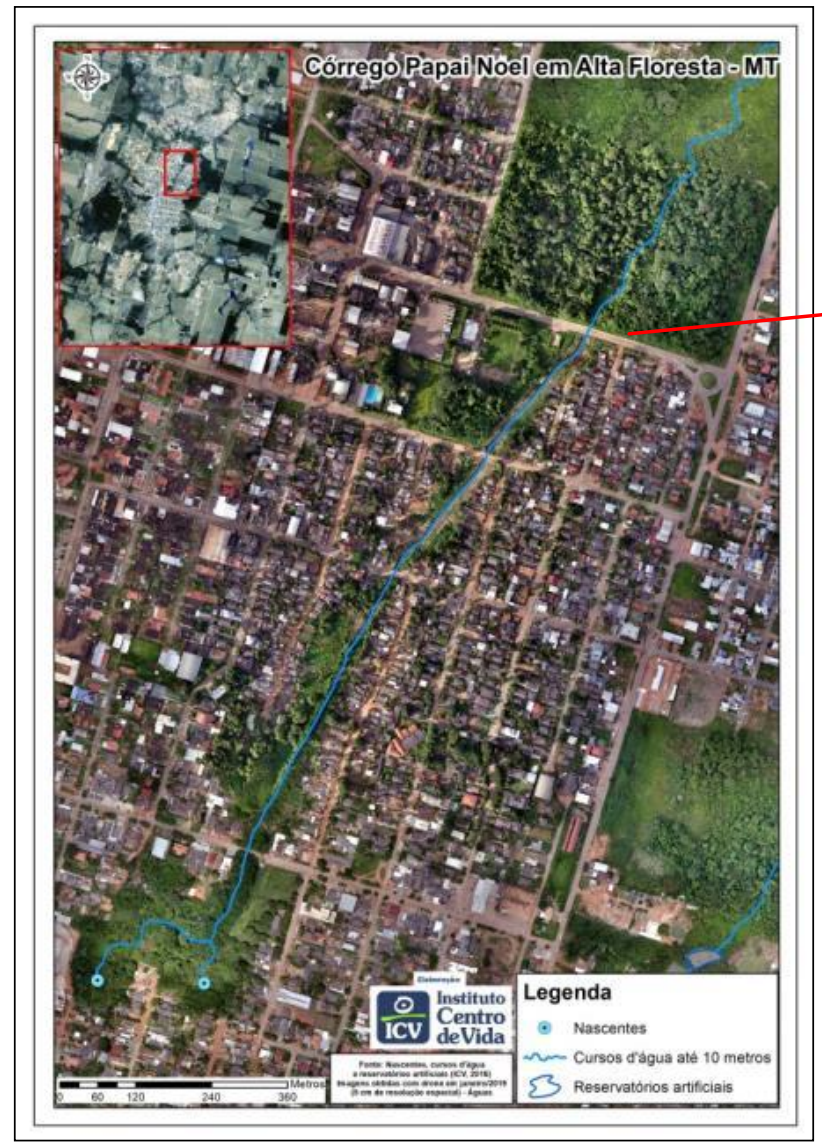

Fonte: Núcleo de Geotecnologias ICV, 2018.

Figura 28: Cobertura florestal em Área de Preservação Permanente do Córrego do Papai Noel e ocupações irregulares.

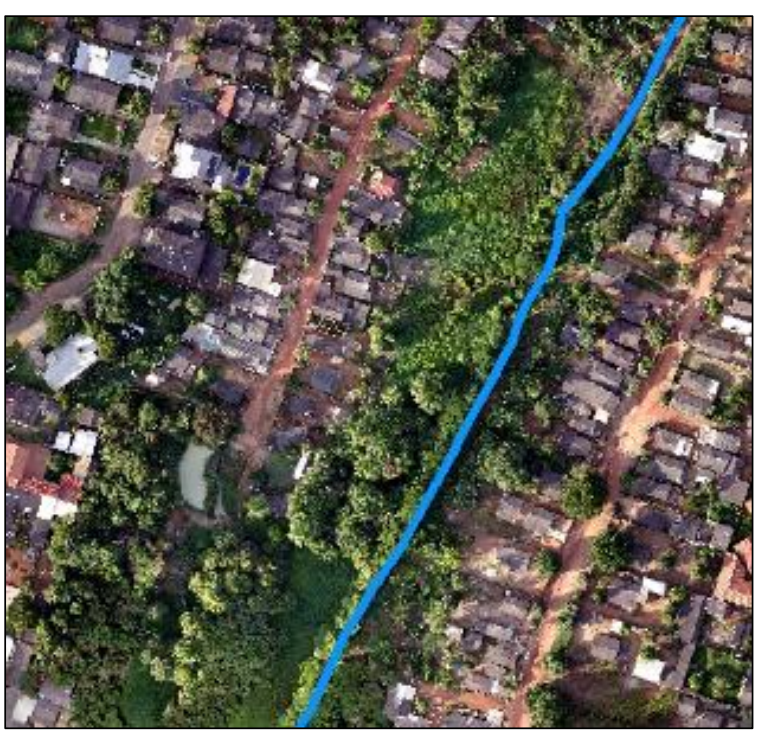

Fonte: Núcleo de Geotecnologias ICV, 2018.
Figura 26: Vista aérea parcial do Parque Leopoldo Linhares Ferreira e da Area de Preservação Permanente do Córrego do Papai Noel.

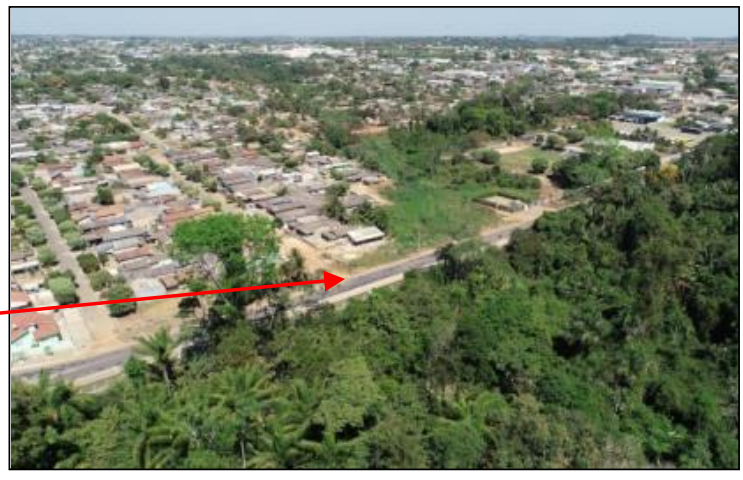

Fonte: Núcleo de Geotecnologias ICV, 2018.

Figura 27: Medidas improvisadas para retenção das águas pluviais provenientes das inundações do Córrego do Papai Noel.

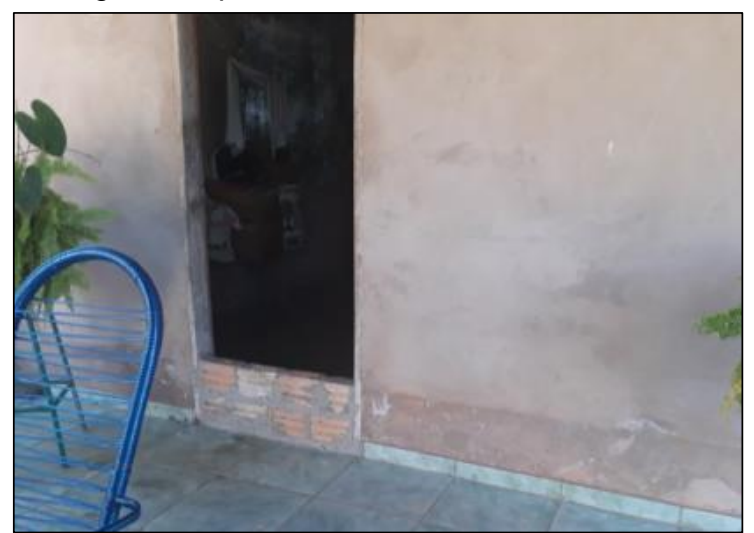

Fonte: Autora 2020

Figura 29: Edificação na Área de Preservação Permanente, em terreno vendido pelo Poder Público.

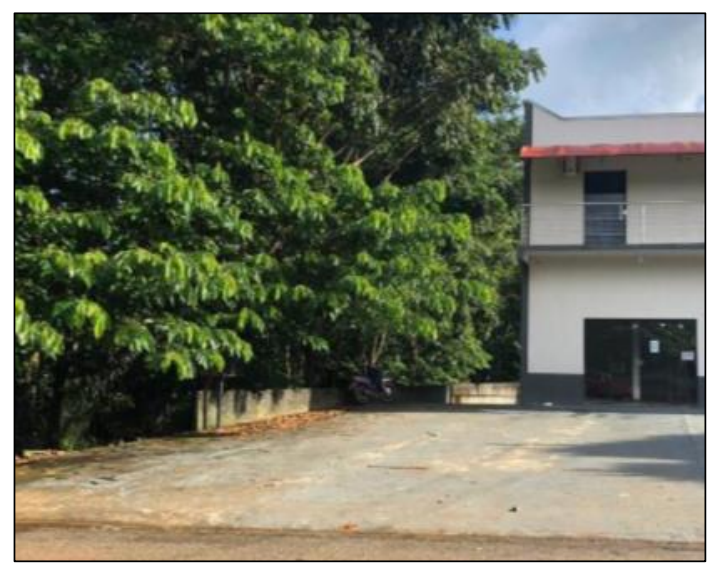

Fonte: Autora 2020. 


\section{- Área de relevância D: Parque Leopoldo Linhares Fernandes.}

O Parque Leopoldo Linhares Fernandes compreende uma área de 17,83 ha, caracteriza-se como um remanescente vegetativo urbano de Floresta Ombrófila Densa em estágio secundário de sucessão, que protege o leito do Córrego do Papai Noel. As áreas vegetadas adjacentes ao Parque compõem o Percurso 1 proposto para a rede de corredores verdes do município, formando um importante mosaico vegetal. Toda a área do Parque é cercada, potencializando sua requalificação para uso da população.

Figura 30: Vista aérea de parte da cidade de Alta Floresta, com ênfase ao Parque Leopoldo Linhares Ferreira (à direita) e Córrego do Papai Noel (à esquerda).

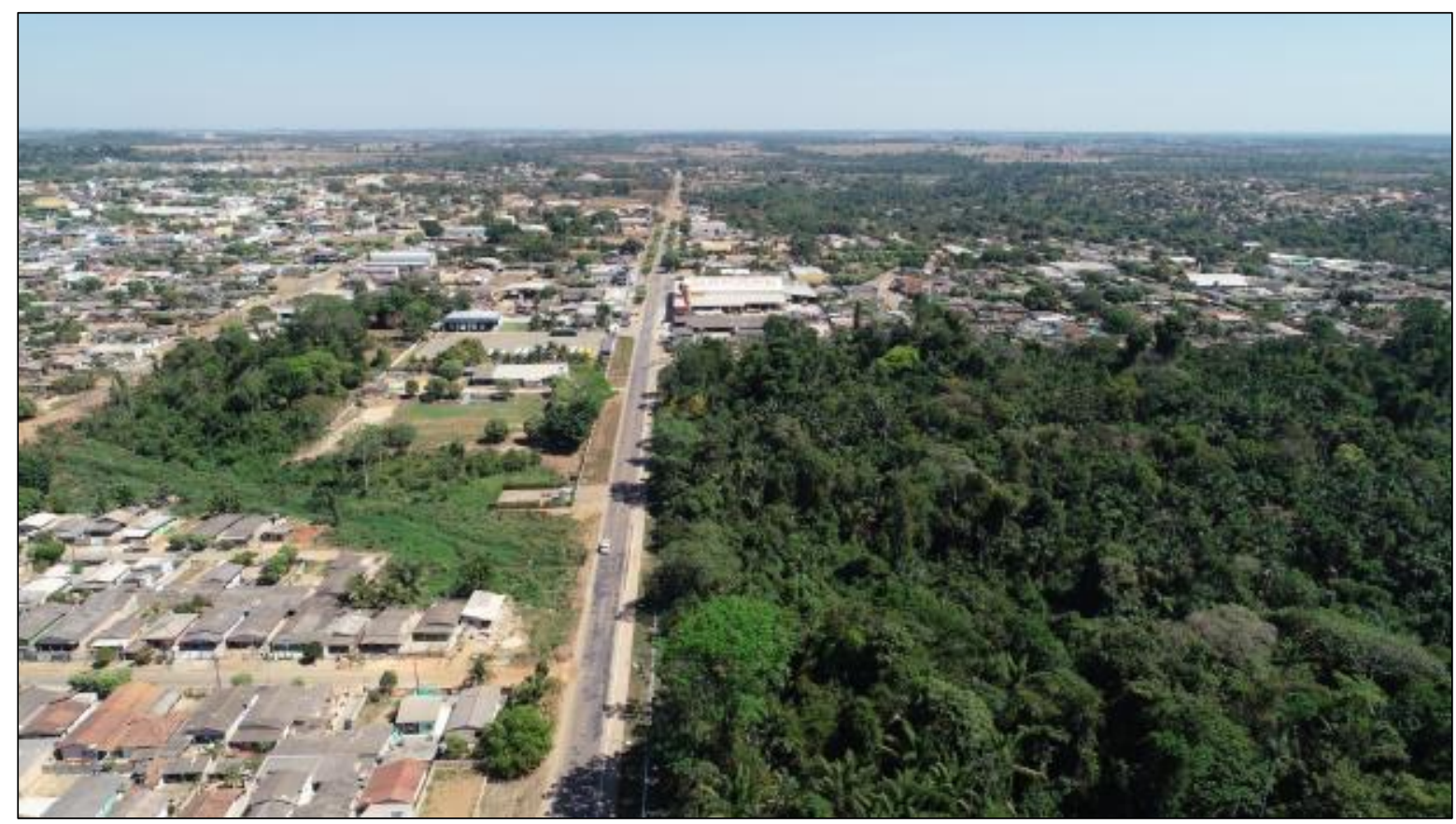

Fonte: Núcleo de Geotecnologias ICV, 2018.

Figura 31: Vista do Parque Leopoldo Linhares Ferreira a partir da Avenida Perimetral.

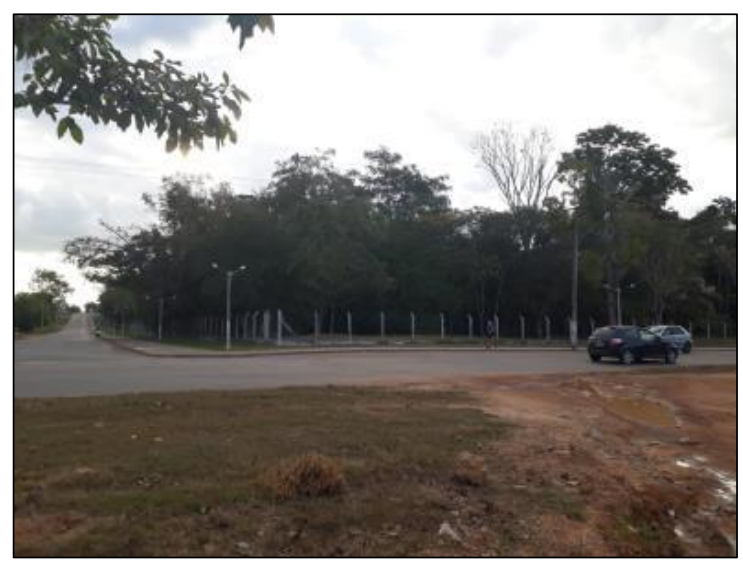

Fonte: Autora 2020.
Figura 32: Vista do Parque Leopoldo Linhares Ferreira a partir de rua local, paralela a Avenida Perimetral.

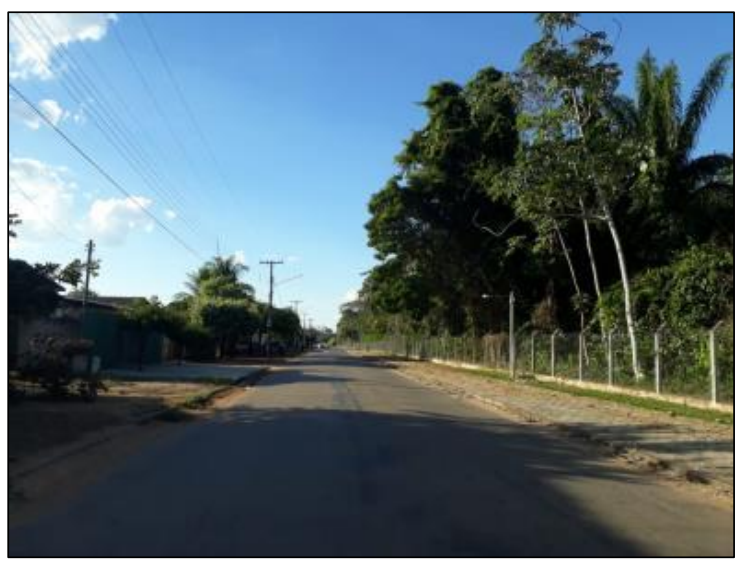

Fonte: Autora 2020

\subsubsection{Análise metodológica das áreas de relevância.}


Os cálculos se basearam na média absoluta para cada grupo ecológico e na média relativa para cada critério adotado, de acordo com os valores obtidos em cada indicador. O valor máximo de pontuação para cada indicador é 1 (um). Sendo assim, têm-se a seguinte classificação: 0 a 0,33 como baixa potencialidade de implantação do corredor verde, de 0,34 a 0,66 como média e de 0,67 a 1 como alta potencialidade de implantação do corredor verde.

Os critérios e indicadores adotados baseiam-se em uma análise comparativa de diferentes métodos utilizados para qualificação de áreas vegetativas, tais como: PBRS (Public Benefit Recording System), Green Network Vacant and Derelict Land Study, HERBST, H. (2001), Califórnia Park Score, THRALL, G; SWANSON, B.; NOZZI, D (1988), URGE (Development of Urban Green Spaces to Improve the Quality of life in Cities and Urban Regions) e Greenspace Quality, compilados por Sanches 2011, com o intuito de obter referências e parâmetros para a criação de uma ferramenta de avaliação adaptada à realidade brasileira.

Dessa forma, têm-se os critérios, os indicadores e os resultados da estrutura ecológica do estudo de caso na tabela abaixo, subdivididos em áreas de relevância caracterizadas no item 3.2.1.

Tabela 1: Análise metodológica das Áreas de Relevância propostas para a Estrutura Ecológica 3.

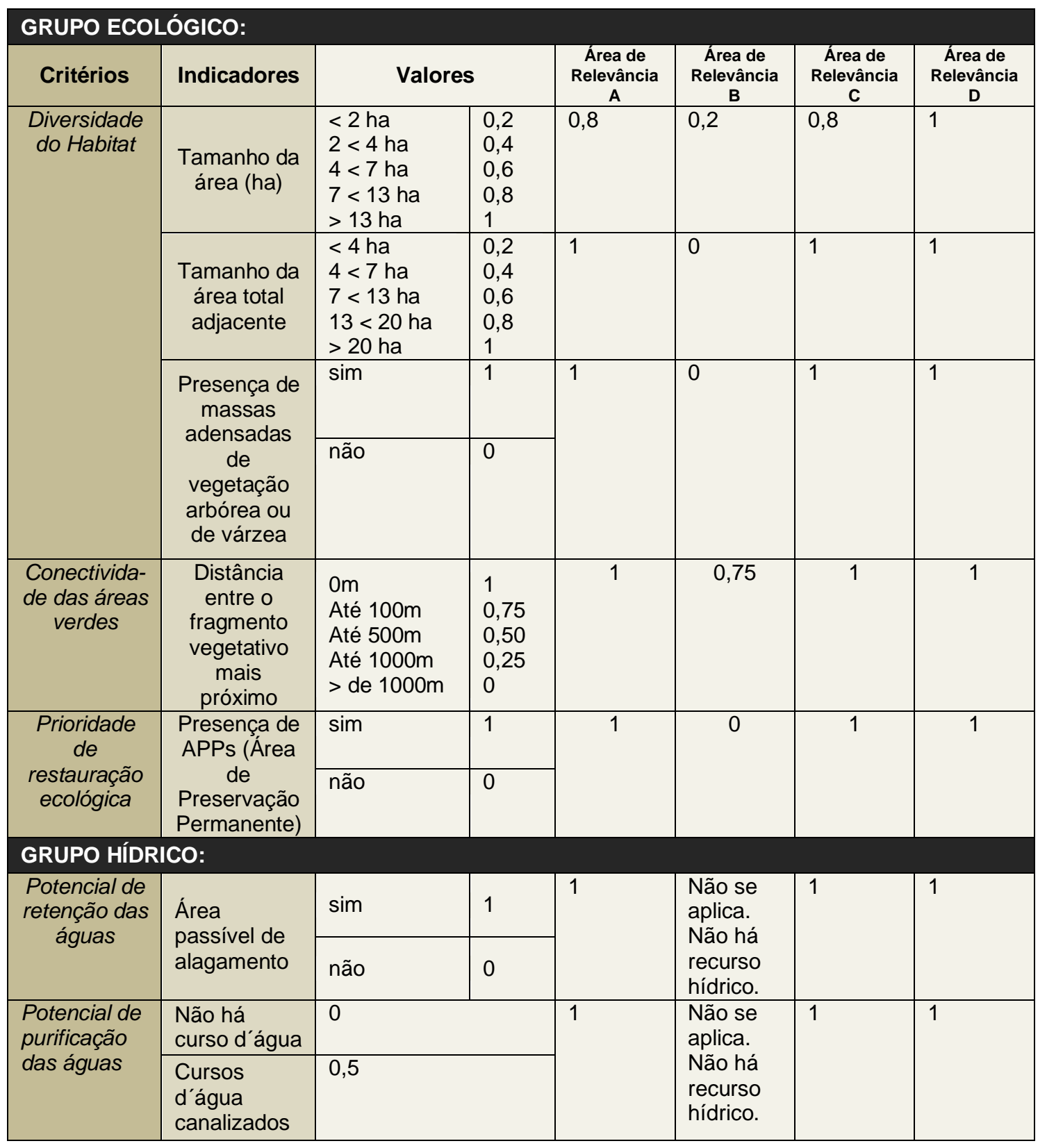




\begin{tabular}{|c|c|c|c|c|c|c|c|}
\hline & $\begin{array}{l}\text { Cursos } \\
\text { d'água não } \\
\text { canalizados }\end{array}$ & \multicolumn{2}{|l|}{1} & & & & \\
\hline & \multirow{2}{*}{$\begin{array}{l}\text { Presença de } \\
\text { vegetação } \\
\text { arbórea ciliar }\end{array}$} & $\operatorname{sim}$ & 1 & \multirow[t]{2}{*}{1} & \multirow{2}{*}{$\begin{array}{l}\text { Não se } \\
\text { aplica. } \\
\text { Não há } \\
\text { recurso } \\
\text { hídrico. }\end{array}$} & \multirow[t]{2}{*}{1} & \multirow[t]{2}{*}{1} \\
\hline & & não & 0 & & & & \\
\hline \multicolumn{8}{|c|}{ GRUPO SOCIAL: } \\
\hline \multirow[t]{3}{*}{ Mobilidade } & \multirow{3}{*}{$\begin{array}{l}\text { Áreas com } \\
\text { dimensões } \\
\text { de quadra } \\
\text { ou lineares } \\
\text { de grande } \\
\text { extensão }\end{array}$} & $\operatorname{sim}$ & 1 & \multirow[t]{3}{*}{1} & \multirow[t]{3}{*}{1} & \multirow[t]{3}{*}{1} & \multirow[t]{3}{*}{1} \\
\hline & & & & & & & \\
\hline & & não & 0 & & & & \\
\hline \multirow{4}{*}{$\begin{array}{c}\text { Acessibilida- } \\
\text { de }\end{array}$} & \multirow{2}{*}{$\begin{array}{l}\text { Acessibilida- } \\
\text { de à área } \\
\text { por } \\
\text { transporte } \\
\text { público }\end{array}$} & sim & 1 & \multirow[t]{2}{*}{0} & \multirow[t]{2}{*}{1} & \multirow[t]{2}{*}{1} & \multirow[t]{2}{*}{1} \\
\hline & & não & 0 & & & & \\
\hline & \multirow{2}{*}{$\begin{array}{l}\text { Presença de } \\
\text { ruas dentro } \\
\text { do } \\
\text { remanescen- } \\
\text { te vegetal }\end{array}$} & $\operatorname{sim}$ & 0 & \multirow[t]{2}{*}{1} & \multirow[t]{2}{*}{1} & \multirow[t]{2}{*}{0} & \multirow[t]{2}{*}{1} \\
\hline & & não & 1 & & & & \\
\hline \multirow[t]{5}{*}{$\begin{array}{c}\text { Potencial de } \\
\text { uso pela } \\
\text { comunidade }\end{array}$} & $\begin{array}{l}\text { Densidade } \\
\text { demográfica }\end{array}$ & \multicolumn{2}{|c|}{$\begin{array}{l}>0-54 \mathrm{hab} / \mathrm{ha}=0,2 \\
54,1-114 \mathrm{hab} / \mathrm{ha}=0,4 \\
114,1-160 \mathrm{hab} / \mathrm{ha}=0,6 \\
160,1-255 \mathrm{hab} / \mathrm{ha}=0,8 \\
>255 \mathrm{hab} / \mathrm{ha}=1\end{array}$} & 0,4 & 0,2 & 0,6 & 0,6 \\
\hline & \multirow{2}{*}{$\begin{array}{l}\text { Uso do solo: } \\
\text { residencial } \\
\text { ou misto }\end{array}$} & $\operatorname{sim}$ & 1 & \multirow[t]{2}{*}{1} & \multirow[t]{2}{*}{1} & \multirow[t]{2}{*}{1} & \multirow[t]{2}{*}{1} \\
\hline & & não & 0 & & & & \\
\hline & \multirow{2}{*}{$\begin{array}{l}\text { Equipamen- } \\
\text { tos culturais } \\
\text { ou escola }\end{array}$} & $\operatorname{sim}$ & 1 & \multirow[t]{2}{*}{0} & \multirow[t]{2}{*}{1} & \multirow[t]{2}{*}{1} & \multirow[t]{2}{*}{1} \\
\hline & & não & 0 & & & & \\
\hline
\end{tabular}

Para o cálculo percentual da potencialidade de implantação do corredor verde na área analisada, utilizou-se a fórmula abaixo, na qual a valoração máxima da potencialidade em questão é $100 \%$, vide fórmula abaixo:

$P=\frac{100 \cdot x}{1}$

Onde:

$\boldsymbol{P}=$ Potencialidade de implantação do corredor verde $\boldsymbol{x}=$ Média dos grupos ecológicos

\section{Resultados e Discussões:}

Os resultados obtidos e a caracterização das áreas propostas para a rede de corredores verdes indicam a grande potencialidade do município para a aplicação da infraestrutura verde como base para o habitar sistêmico urbano. Tanto a proximidade entre os fragmentos vegetados urbanos quanto os largos recuos subutilizados nas margens das vias públicas, favorecem a possibilidade de conexão entre as áreas de relevância por corredores verdes. De acordo com a valoração dos critérios e indicadores utilizados neste artigo, obteve-se como valor absoluto, a resultante de $83,3 \%$ de potencial para a estrutura ecológica em análise, sendo $100 \%$ o resultado máximo a ser alcançado. Os valores relativos para cada trecho analisado são de 87\% para a Área de Relevância A, 59\% para a Área de 
Relevância B, 87\% para a Área de Relevância C, e 100\% para a Área de Relevância D, subdivididos nos grupos funcionais conforme a tabela abaixo:

Tabela 2: Valores potenciais para cada grupo funcional analisado:

\begin{tabular}{|c|c|c|c|}
\hline $\begin{array}{l}\text { ÁREA DE } \\
\text { RELEVÂNCIA: }\end{array}$ & $\begin{array}{l}\text { GRUPO } \\
\text { ECOLÓGICO: }\end{array}$ & GRUPO HÍDRICO: & GRUPO SOCIAL: \\
\hline$A$ & $\begin{array}{l}0,96 \text { - Alta } \\
\text { potencialidade }\end{array}$ & $\begin{array}{l}1,00-\text { Alta } \\
\text { potencialidade }\end{array}$ & $\begin{array}{l}0,66 \text { - Média } \\
\text { potencialidade }\end{array}$ \\
\hline$B$ & $\begin{array}{l}0,19 \text { - Baixa } \\
\text { Potencialidade (praça } \\
\text { edificada, tratada } \\
\text { aqui como um eixo } \\
\text { de ligação entre as } \\
\text { manchas vegetais). }\end{array}$ & $\begin{array}{l}\text { Não se aplica. Não } \\
\text { há recurso hídrico. }\end{array}$ & $\begin{array}{l}1,00-\text { Alta } \\
\text { potencialidade }\end{array}$ \\
\hline$C$ & $\begin{array}{l}0,96 \text { - Alta } \\
\text { potencialidade }\end{array}$ & $\begin{array}{l}1,00-\text { Alta } \\
\text { potencialidade }\end{array}$ & $\begin{array}{l}\text { 0,66 - Média } \\
\text { potencialidade }\end{array}$ \\
\hline$D$ & $\begin{array}{l}1,00-\text { Alta } \\
\text { potencialidade }\end{array}$ & $\begin{array}{l}1,00-\text { Alta } \\
\text { potencialidade }\end{array}$ & $\begin{array}{l}1,00-\text { Alta } \\
\text { potencialidade }\end{array}$ \\
\hline
\end{tabular}

O método avaliativo desenvolvido tem caráter preliminar para a qualificação das áreas em questão e necessita de uma análise aprofundada para que se possibilite sua implantação, considerando outras variáveis, tais como estudos técnicos multidisciplinares, viabilidade econômica, etc. A ferramenta metodológica desenvolvida, baseada no referencial teórico compilado por Sanches 2011, constitui-se em um direcionamento que poderá ser aplicado em outros municípios, com indicadores e critérios adaptados à realidade local de acordo com as características de cada lugar. Sendo assim, caracterizase como uma contribuição prática para o planejamento urbano ambiental e sistêmico de cidades que buscam ampliar a qualidade de vida de seus habitantes integradas aos recursos naturais presentes.

\section{Conclusão:}

O presente artigo aplicou princípios de infraestrutura verde no perímetro urbano de Alta Floresta Mato Grosso como meio de planejar e gerir a cidade de forma resiliente, ecológica e sistêmica. Teve como premissa a valorização dos elementos naturais locais como forma de prover benefícios fundamentais ao habitat urbano e qualificou, por meio da amostragem de uma das estruturas ecológicas criadas, a alta a potencialidade de implantação de um sistema multifuncional de serviços ambientais e sociais no município de Alta Floresta, Mato Grosso, Brasil.

Pautado no desenvolvimento sustentável urbano, ressalta que a infraestrutura verde é um instrumento estratégico capaz de criar e reestruturar espaços citadinos através da gestão de serviços ecossistêmicos dinâmicos, se apropriando da Natureza como solução para responder às demandas e desafios encontrados no meio urbano com a consolidação de paisagens de alta performance.

\section{Referências Bibliográficas:}

BENEDICT, M; MCMAHON, E (2006) Green Infrastructure. Linking Landscapes and Communities, Island Press, London

BONZI, R. S. Emerald Necklace: infraestrutura urbana projetada como paisagem. LABVERDE. São Paulo: FAUUSP, n. 9, dez. 2014, p. 106-127.

CAPRA, Fritjof. A Teia da Vida: Uma Nova Compreensão Científica dos Sistemas Vivos. 9a ed. Trad. Newton Roberval Eichemberg.. São Paulo, SP: Editora Pensamento - Cultrix Ltda, 2004.

FERREIRA, J. C. (2010), Estrutura Ecológica e Corredores Verdes - estratégias territoriais para um futuro urbano sustentável in Pluris 2010 - 4ํㅡㄹ Congresso LusoBrasileiro para 0 Planeamento Urbano, Regional, Integrado, Sustentável, Faro. 
FERREIRA, J. C., \& MACHADO, J. (2010). Infra-estruturas verdes para um futuro urbano sustentável. $O$ contributo da estrutura ecológica e dos corredores verdes. Revista $L A B V E R D E$ (1), 69-90.

FORMAN, Richard T.; DRAMSTAD, W.E.; OLSON, J.D. Landscape Ecology Principles in Landscape Architecture and Land-Use Planning. Washington, DC: Island Press, 1996.

FORMAN, Richard T. T.. Land Mosaics: The ecology of landscapes and regions. Cambridge,UK : Cambridge University, 1995.

FREITAS, J. (2017). Construindo para a (Bio)Diversidade: o planejamento ecológico da paisagem urbana. Paisagem E Ambiente, (40), 89-103.

HERBST, $\mathrm{H}$. The importance of wasteland as urban wildlife areas - with particular reference to the cities Leipzig and Birmingham. 2001, 161p. Tese (Doutorado em Ciências Naturais) - Faculdade de Física e Geografia, Universidade de Leipzig, 2001

METZGER, J.P. O que é ecologia das paisagens? Revista Biota Neotrópica, 1 (1/2): 1-9. Campinas, 2001.

NACIFF, Y. D. DAS N. . O pensamento sistêmico em análises urbanas: uma perspectiva para o problema da segregação socioespacial nas cidades. Arquitetura e Urbanismo, n. 24, p. 1-18, 1 jan. 2019.

RIBEIRO, M. E. J. Infraestrutura verde, uma estratégia de conexão entre pessoas e lugares: por um planejamento urbano ecológico para Goiânia. 2010. Tese (Doutorado) - Faculdade de Arquitetura e Urbanismo, Uniersidade de São Paulo, São Paulo.

SANCHES, P. M. De áreas degradadas a espaços vegetados: potencialidades de áreas vazias, abandonadas e subutilizadas como parte da infra-estrutura verde urbana. 2011. Dissertação (Mestrado) - Faculdade de Arquitetura e Urbanismo, Universidade de São Paulo, São Paulo, 2011.

SILVA, L. B. D. D. BATISTA, L. A. D. S.; SILGUEIRO, V. D. F.; BUTTURI, W.; SANTOS, B. D.C.D. Uso de imagens obtidas por drone para o mapeamento da cobertura florestal na área urbana de Alta Floresta MT In: VII Seminário de Biodiversidade e Agroecossistemas Amazônicos: Biodiversidade e a Integração Lavoura-Pecuária-Floresta nos Agroecossistemas Amazônicos, 7ª . (SEBAAM), 2019, Alta Floresta/MT.

STAPLES, Mike (Coord). Green Network Vacant and Derelict Land Study for Glasgow and Clyde Valley Structure Plan. Joint Committee. Edinburgh: RPS, 2006. Disponível em: < http://www.gcvgreennetwork.gov.uk/. >. Acesso em: 06/2020.

TOPANOTTI, V.P. Plano Urbanístico de Alta Floresta - MT: Contradições do planejamento urbano autoritário. 2016. Dissertação (Doutorado em Urbanismo) - Departamento de Arquitetura e Urbanismo, Universidade Federal do Rio de Janeiro, Rio de Janeiro.

THRALL, G; SWANSON, B.;NOZZI, D. Greenspace Acquisition and Ranking Program (GARP): a computer-assisted decision strategy. Computers, Environment and Urban Systems, Vol. 12, 161-184, 1988.

URGE. Development of Urban Green Spaces to Improve the Quality of Life in Cities and Urban Regions. Leipzig, Germany: UFZ, 2004. 


\section{Patrícia Latuf Marba}

Arquiteta e Urbanista formada pela PUCCAMP em 2007, especialista em Reabilitação Ambiental Sustentável Arquitetônica e Urbanística (Reabilita) em 2020, desenvolve, desde a graduação, projetos de arquitetura de baixo impacto ambiental e tecnologias sociais sustentáveis em residências, empreendimentos e comunidades. Conselheira do COMDEMA de Alta Floresta, MT e sócia-fundadora da Associação Guadalupe Agroecológica em Alta Floresta, MT.

Contribuição de coautoria: fundamentação teórico-conceitual e problematização.

\section{Rodrigo Studart Corrêa}

Docente do Programa de Pós-Graduação em Ciências Ambientais (PPGCA) da Faculdade UnB Planaltina (FUP) da Universidade de Brasília (UnB). Docente do Curso de pós graduação lato sensu em Reabilitação Ambiental Sustentável Arquitetônica e Urbanística (Reabilita), Faculdade de Arquitetura e Urbanismo (FAU), Universidade de Brasília (UnB).

Contribuição de coautoria: fundamentação teórico-conceitual e problematização.

Como citar: MARBA, Patrícia Latuf, CORRÊA, Rodrigo Studart. Potencialidades da Infraestrutura Verde para um Habitar Sistêmico no Meio Urbano de Alta Floresta - MT. Revista Paranoá. n.30. Edição Temática: Olhares da Reabilitação Sustentável 3, 2021. DOI 10.18830/issn.16790944.n30.2021.09

Editores responsáveis: Caio Frederico e Silva e Daniel Richard Sant'anna 